\title{
Pseudomonas syringae pv. actinidiae: Ecology, Infection Dynamics and Disease Epidemiology
}

\author{
Irene Donati ${ }^{1}$ - Antonio Cellini ${ }^{1}$ - Daniela Sangiorgio ${ }^{1}$ - Joel L. Vanneste ${ }^{2} \cdot$ Marco Scortichini $^{3} \cdot$ Giorgio M. Balestra $^{4}$. \\ Francesco Spinelli ${ }^{1}$
}

Received: 25 February 2019 / Accepted: 4 November 2019 / Published online: 3 January 2020

(C) Springer Science+Business Media, LLC, part of Springer Nature 2020

\begin{abstract}
Since 2008, the kiwifruit industry has been devastated by a pandemic outbreak of Pseudomonas syringae pv. actinidiae (Psa), the causal agent of bacterial canker. This disease has become the most significant limiting factor in kiwifruit production. Psa colonizes different organs of the host plant, causing a specific symptomatology on each of them. In addition, the systemic invasion of the plant may quickly lead to plant death. Despite the massive risk that this disease poses to the kiwifruit industry, studies focusing on Psa ecology have been sporadic, and a comprehensive description of the disease epidemiology is still missing. Optimal environmental conditions for infection, dispersal and survival in the environment, or the mechanisms of penetration and colonization of host tissues have not been fully elucidated yet. The present work aims to provide a synthesis of the current knowledge, and a deeper understanding of the epidemiology of kiwifruit bacterial canker based on new experimental data. The pathogen may survive in the environment or overwinter in dormant tissues and be dispersed by wind or rain. Psa was observed in association with several plant structures (stomata, trichomes, lenticels) and wounds, which could represent entry points for apoplast infection. Environmental conditions also affect the bacterial colonization, with lower optimum values of temperature and humidity for epiphytic than for endophytic growth, and disease incidence requiring a combination of mild temperature and leaf wetness. By providing information on Psa ecology, these data sets may contribute to plan efficient control strategies for kiwifruit bacterial canker.
\end{abstract}

Keywords Actinidia chinensis Planch. var. chinensis · Actinidia chinensis var. deliciosa (A.Chev.) - Temperature $\cdot$ Relative humidity $\cdot$ Confocal laser scanning microscopy $(\mathrm{CLSM}) \cdot$ Overwintering

Electronic supplementary material The online version of this article (https://doi.org/10.1007/s00248-019-01459-8) contains supplementary material, which is available to authorized users.

Francesco Spinelli

francesco.spinelli3@unibo.it

1 Department of Agricultural and Food Sciences, Alma Mater Studiorum-University of Bologna, viale Fanin 46, 40127 Bologna, Italy

2 The New Zealand Institute for Plant \& Food Research Ltd, Ruakura Research Centre, Bisley Road, Ruakura, Private Bag 3123, Hamilton 3240, New Zealand

3 Council for research in agriculture and economics (CREA), Research Centre for Olive, Fruit Trees and Citrus, Via di Fioranello, 52, I-00134 Rome, Italy

4 Department for Agriculture and Forest Sciences (DAFNE), University of Tuscia, Via S. Camillo de Lellis snc -, 01100 Viterbo, Italy

\section{Introduction}

Kiwifruit [Actinidia chinensis Planch. var. chinensis and Actinidia chinensis var. deliciosa (A. Chev.)] production, which is mostly concentrated in China, Italy and New Zealand, generates a significant agricultural value of over three billion euros annually, with a retail market value worth over ten billion euros (FAO data, 2017). The emergence and spread in all the key production areas of Pseudomonas syringae pv. actinidae (Psa), responsible for bacterial canker of kiwifruit, has compromised the viability of this production on a global scale [1-6]. The pathogen is highly virulent, spreading quickly between plants of different cultivars and vines of different ages [5-8]. For example, in Italy, between 2010 and 2012, more than 2000 ha of kiwifruit orchards have been either destroyed by the disease or cut down, causing severe economic losses for growers, satellite industries, and other stakeholders of the kiwifruit production chain [9]. 
Because of its recent and rapid emergence, the biology and ecology of Psa biovar 3, responsible for the pandemic outbreak of kiwifruit bacterial canker, has not yet been fully elucidated $[3,5,6]$. The information available on well-studied, related $P$. syringae pathovars, such as $P$. syringae pv. syringae, may provide general indication on conspecific bacteria. However, because of the strict host specificity, molecular and biochemical peculiarities must exist in Psa, and many aspects of this pathovar biology and disease epidemiology still require in-depth investigation. Primary entry points and mechanisms of spread of Psa represent important aspects still to elucidate. This information is the key to assist in the development of effective means of disease control which should be tailored on the key steps of the disease cycle.

This work aims to elucidate the so far unresolved points in the epidemiology of bacterial canker, with a particular focus on the sources of inoculum and on the sites of infection. Some short communications have listed plant tissues where the bacteria have been detected [10-12]: lenticels, lesion margins, buds, woody tissue, suckers and fruit pedicels. However, such studies provided no evidence for direct tissue contamination, since Psa can migrate through the apoplast leading to a systemic plant infection. Further studies identified natural openings and lesions as important entry sites for Psa, as well as the importance of lenticels and fresh cut in the infection process, as observed through a scanning electron microscope [13, 14]. Furthermore, it was observed, through bacterial injections into leaf veins as described by Serizawa and Ichikawa [15], that bacteria can migrate from young leaves to twigs facilitating a systemic infection throughout the vine $[8,12,13,16-18]$. The bacterium was retrieved in xylem vessels and phloem tissues, indicating that the systemic spread can rapidly reach potentially any tissue of the infected plant [14].

However, the methods used to obtain these results have inherent limitations. The manipulation of plant material required to prepare the samples for the scanning electron microscope is well known to generate artefacts in the quantity and distribution of bacteria in the plant samples [19]. A less biassed method of observation is the use of the confocal laser scanning microscope (CLSM), in which plant material is not manipulated by treatments such as staining and fixing, providing a more accurate observation of bacteria distribution directly in vivo [19]. Furthermore, with the use of autofluorescent protein labelling, bacterial movement can be tracked visually in live plant tissues, providing more accurate information on migration through the plant $[10,14,19]$.

Large variability within the Actinidia Lindl. genus exists due to the large natural geographic range in which these plants are found [20]. The main cultivated varieties are A. chinensis var. chinensis and $A$. chinensis var. deliciosa, the former being characterized by yellow- or red-fleshed fruit, while the latter includes primarily green-fleshed cultivars [21]. However, between A. chinensis var. chinensis and A. chinensis var. deliciosa, there are differences not only in vegetative morphology, flower and fruit morphology, and chromosome number [20, 22-24] but also in different susceptibility to Psa. In fact, it has been observed that yellow- and red-fleshed kiwifruit (A. chinensis var. chinensis) are generally more susceptible than green-fleshed (A. chinensis var. deliciosa) cultivars such as 'Hayward' displaying a more pronounced symptomatology, enhanced spread, and faster dieback [25].

Possible explanations for differences in response to the Psa infection include variation in morphology features such as a higher density of lenticels and stomata and a larger leaf surface area [26]. However, as for other pathogenic bacteria showing an epiphytic phase, factors that contribute to the creation of favourable leaf microhabitat conditions should not be overlooked [27, 28].

Understanding the disease epidemiology has significant practical applications in the improvement of disease management. A clear elucidation of the importance of entry points that may vary throughout the season, can enable fine-tuned disease management strategies based on the plant-pathogen phenological synchrony for enhanced plant protection. Furthermore, cultivar factors influencing host-pathogen interactions are central for the appropriate selection of resistance genotypes in breeding programmes [29].

This paper aims to evaluate the key steps of the infection process and the influence of the environmental factors on Psa growth and infection. Furthermore, the relative importance of the possible entry points of Psa, the colonization pathway, the environmental survival of the pathogen and its spread from plant to plant are determined.

The study was conducted both in controlled and field conditions in Italy and New Zealand. In controlled conditions, the inoculation of host plants was performed with the use of GFPlabelled bacteria and to allow for a non-invasive, real-time observation under CLSM of the plant-pathogen interactions both at the cell and whole plant level. Furthermore, the investigation of the successful colonization of Psa through various entry points in the two different species allowed to draw new hypotheses for the different susceptibility between A. chinensis var. chinensis and A. chinensis var. deliciosa.

\section{Materials and Methods}

\section{Plant Material}

The experiments in controlled conditions were performed on 1- to 3-year-old potted plants of A. chinensis var. deliciosa cv. 'Hayward', or A. chinensis var. chinensis cvs. 'Zesy002' (Gold3), 'Jintao' and 'Hort16A', A. arguta (Siebold \& Zucc.) Planch. Ex Miq, A. polygama (Siebold \& Zucc.) Maxim. and A. eriantha Bentham grown in a mixture of peat and sand $(1: 1, \mathrm{v} / \mathrm{v})$ with standard irrigation and fertilization, 
and maintained in a growth chamber with a $16: 8 \mathrm{~h}$ (light/dark) photoperiod. Normal growth conditions were $24{ }^{\circ} \mathrm{C}$ and approximately $85 \%$ relative humidity $(\mathrm{RH})$. Semi-field experiments were performed on 4- to 5-year-old potted plants of A. chinensis var. deliciosa cv. 'Hayward', or A. chinensis var. chinensis cv. 'Hort16A'.

Field experiments were carried out in commercial orchards of $A$. chinensis var. deliciosa cv. 'Hayward' or cv. 'Tomuri' or 'Matua' and A. chinensis var. chinensis cv. 'Jintao' or cv. 'Hort16A' located near Faenza F (44 $17^{\prime} 8^{\prime \prime} \mathrm{N}$; 11 120 53' $\left.0^{\prime \prime} \mathrm{E}\right)$, Sarna ( $44^{\circ} 15^{\prime} 13^{\prime \prime} \mathrm{N}$; $\left.11^{\circ} 52^{\prime} 50^{\prime \prime} \mathrm{E}\right)$ and Imola (44 $37^{\prime}$ $\left.42^{\prime \prime} \mathrm{N}, 11^{\circ} 68^{\prime} 85^{\prime \prime} \mathrm{E}\right)$. In all the studied orchards, at the beginning of the experiments, the incidence of bacterial canker was approximately $50 \%$, assessed by monitoring of visual symptoms on vines. To monitor the microclimate conditions, humidity (EasyLog-UBS-1), temperature and leaf wetness (Spectrum data-loggers 1000 Series Micro Stations) sensors were placed in each orchard. Rainfalls data was obtained by Dexter Service of Regione Emilia Romagna (Italy).

\section{Field Monitoring of Symptoms}

During three seasons (2013-2015), the presence of bacterial canker symptoms was recorded on a population of canes in five commercial orchards. In the same locations, meteorological data were also collected.

The canes were selected and tagged in March. The symptom assessment was performed weekly from April to November, by recording the number of bacterial canker lesions on the leaves. Starting from 2014, to obtain timely information on the bacterial spread in the orchard, potted sentinel plants of $A$. chinensis var. deliciosa (cvs. 'Hayward' and 'Tomuri') were placed weekly under the canopy of three of the commercial orchards. After a 7-day exposure, Psa populations were determined in six sentinel plants, while six more were maintained in a greenhouse for 3 weeks before leaf spots were recorded.

\section{Bacterial Growth, Inoculation and Quantification}

For experiments in controlled conditions, transgenic Psa strains, derived from CFBP7286 (biovar 3), isolated in Italy from $A$. chinensis var. chinensis, retaining the wild-type virulence and expressing a green CFBP7286-GFPuv or red CFBP7286-DsED fluorescent proteins were used for experimental inoculation [10]. Bacteria were grown in liquid Lysogenic Broth medium $\left(27{ }^{\circ} \mathrm{C}\right.$, under agitation at $120 \mathrm{rpm}$ ) for 2 days, then precipitated by centrifugation and resuspended in sterile $10 \mathrm{mM} \mathrm{MgSO}_{4}$.

Potted plants were inoculated with a bacterial suspension (approx. $10^{7} \mathrm{CFU} \mathrm{mL}^{-1}$ ) according to the target entry point. In all cases, the plants were kept at $100 \% \mathrm{RH}$ for $48 \mathrm{~h}$ post inoculation. For each experimental condition, 5-8 biological replicates were used in a randomized block design.

Leaf scars on A. chinensis var. deliciosa and A. chinensis var. chinensis canes were inoculated with $20-\mu \mathrm{L}$ drops of bacterial suspension (approx. $10^{7} \mathrm{CFU} \mathrm{mL}^{-1}$ ) after natural leaf fall or mechanical removal of the leaf. The inoculation was performed 1, 2, 3, 4 or 15 days after detachment. Ten days after inoculation, the samples were surface-sterilized and Psa endophytic population was determined.

Pruning cuts were inoculated as described for leaf scars. Inoculation was performed up to 32 days after pruning. Host colonization was assed 10 days after inoculation as previously described.

Closed (BBCH 00) or swollen (BBCH 03) [30] buds were inoculated by applying for $24 \mathrm{~h}$ a cotton plug soaked in bacterial suspension. Ten days later, the phenological stage of the bud (bud swelling, BBCH 01-03; bud burst, BBCH 07; sprouting buds, BBCH 09) was recorded, and Psa population was determined. Lenticels were inoculated using the same protocol. The penetration of Psa through the lenticel was determined 7-40 days post inoculation by excising the surrounding tissue and using its internal face to inoculate Lysogenic Broth Agar medium amended with cycloheximide (100 $\left.\mathrm{mg} \mathrm{L}^{-1}\right)$ and kanamycin $\left(50 \mathrm{mg} \mathrm{L}^{-1}\right)$.

Host invasion through natural openings on leaves (stomata, trichomes) was tested by directly spraying the bacterial suspension on the target organs. Female flowers were inoculated by brushing stigmas with contaminated pollen, whilst male flowers were sprayed with a bacterial suspension. Roots were inoculated by dipping in the bacterial suspension for $1 \mathrm{~min}$. Subsequently, the plants were placed in sterile sand until analysis. Host colonization was assed 1, 3, 7, 14, 21 and 30 days after inoculation according to the different inoculated organ.

Epiphytic bacterial populations were obtained by washing the samples in $10 \mathrm{mM} \mathrm{MgSO}_{4}$ for 30 min under energic agitation $(150 \mathrm{rpm})$. To assess the growth of the pathogen within the tissues, the plant samples were surface-sterilized by 1-min washes in $70 \%$ ethanol, $1.5 \% \mathrm{NaOCl}$, and twice in sterile water, then homogenized in $10 \mathrm{mM} \mathrm{MgSO}_{4}$. The bacterial concentrations (colony-forming units per $\mathrm{mL}, \mathrm{CFU} \mathrm{mL}^{-1}$ ) were determined by plating sequential tenfold dilutions of the bacterial suspensions on agarised Lysogenic Broth medium amended with cycloheximide $\left(100 \mathrm{mg} \mathrm{L}^{-1}\right)$. The molecular identity of dubious colonies, and the overall reliability of the method were confirmed with a PCR recognition and quantification protocol [31].

\section{Visualization of Colonization and Migration inside the Host Tissues}

Psa colonization of the host plant was monitored by fluorescent microscopy and confocal laser scanning microscopy. Microscopical observation of samples inoculated with 
fluorescent bacteria was performed using a motorized microscope (SMZ25, Nikon, Tokyo, Japan) fitted with a BHS (GHS) filter set (excitation light 450-490 nm, emission $510 \mathrm{~nm}$ ) used to visualize the fluorescent bacteria. Optical sections were obtained with a $\mathrm{C} 1-\mathrm{S}$ confocal laser scanning microscope (CLSM) equipped with an Argon laser. PlanApo objectives 40, 60 and 100× (Nikon, Tokyo, Japan) and BHS (GHS) filter set were used for image acquisition. Images were acquired and analysed by the NIS-Elements C Microscope Imaging Software (Nikon, Tokyo, Japan).

The rates of Psa migration through plant tissues were calculated by determining the endophytic bacterial population in several plant organs, accounting for distance from the inoculation point and acropetal/basipetal direction. Actinidia chinensis var. deliciosa (cv. 'Hayward') and A. chinensis var. chinensis (cv. 'Hort16A') plants were stab-inoculated on the stem. Three weeks or 4 months later, Psa populations were determined in 1-cm samples taken above and below the inoculation point. For each variety, three plants for each time point were inoculated. Maximum linear migration rates were also calculated from freshly excised canes, immersed in bacterial suspension $\left(7.3 \times 10^{5} \mathrm{CFU} \mathrm{mL}{ }^{-1}\right)$ diluted in $10 \mathrm{mM} \mathrm{MgSO}_{4}$ and maintained at approx. 95\% RH. After 20 days, samples of wood tissue were taken every $10 \mathrm{~cm}$ to determine the furthest distance where Psa could be found.

\section{Influence of Temperature and Relative Humidity on Psa Growth in Plants}

The infection threshold was evaluated on the four main cultivars of $A$. chinensis var. chinensis and A. chinensis var. deliciosa, i.e. 'Zesy002', 'Hort16A', 'Jintao' and 'Hayward'. Experimental inoculations were performed in controlled conditions on 3-year-old potted plants. The experiment was repeated three times, and each repetition consisted in 30 plants per cultivar divided in three biological replicates of ten plants. Half of the plants were spray-inoculated with a wild type strain of Psa (CFBP7286, biovar 3) and the other half with a GFPuv-Psa in order to visualize the colonization of the plant tissues. Plants were inoculated with increasing concentrations of the pathogen

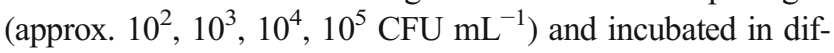
ferent temperature and humidity combinations (Table 1).

Psa endophytic population was quantified at 3, 6, 24, 48, 72,96 and $120 \mathrm{~h}$ post-inoculation. Symptoms were assessed at 7, 14 and 21 days post-inoculation. The infection threshold was calculated according to the following equation:

$I T=A V G_{T, R H} \frac{P_{t}+P_{t-1}}{2}$

$t$ : first time point where an endophytic population was found in a specific range of temperature (T) and humidity $(\mathrm{RH})$.

$P_{t}$ : epiphytic Psa population at the time point $\mathrm{T}$.
Table 1 Combinations of temperature and relative humidity tested $(\sqrt{ })$ for assessing epiphytic and endophytic growth of Pseudomonas syringae pv. actinidiae in Actinidia chinensis var. chinensis and A. chinensis var. deliciosa plants

\begin{tabular}{lllll}
\hline Temperature $\left({ }^{\circ} \mathrm{C}, \pm 2\right)$ & \multicolumn{4}{l}{ Relative Humidity $(\%, \pm 5)$} \\
\cline { 2 - 5 } & 20 & 65 & 75 & 90 \\
\hline 0 & & & $\sqrt{ }$ & \\
5 & & $\sqrt{ }$ & \\
7 & & $\sqrt{ }$ & \\
16 & & $\sqrt{ }$ & \\
21 & $\sqrt{ }$ & $\sqrt{ }$ & $\sqrt{ }$ & $\sqrt{ }$ \\
24 & & & $\sqrt{ }$ & \\
35 & & & $\sqrt{ }$ & \\
40 & & & & \\
\hline
\end{tabular}

$P_{t-1}$ : epiphytic Psa population at the time point prior T.

AVG: average of all the combinations of temperature and humidity.

Bacterial growth rates were calculated in the logarithmic phase. For each combination of temperature and RH, the first time point in which an endophytic Psa population occurred $\left(T_{n}\right)$ was considered to estimate the infection threshold. This value was calculated as the average between epiphytic populations at $T_{n}$ and $T_{n-1}$.

\section{Survival of Psa in Asymptomatic Plant Material, Soil, Water and Non-host Species}

The experiments were carried out in two commercial orchards of $A$. chinensis var. chinensis and A. chinensis var. deliciosa located in Faenza (Emilia-Romagna, Italy). Further experiments were conducted in controlled conditions with experimental contamination of the different substrates.

To assess Psa survival on litter and pruning wood, symptomatic leaves and dieback pruned twigs and canes were collected at leaf fall from an A. chinensis var. chinensis and A. chinensis var. deliciosa orchards. The leaves and pruning woods from the two species were mixed together in equal parts and enclosed in a plastic net (2-mm mesh). Each plastic net was left on the orchard for 6 months. Four samples (10 g each) were collected weekly to determine Psa population. In addition, climatic data were collected during the whole experiment. Finally, samples of healthy leaves and pruning wood were experimentally inoculated and incubated in controlled conditions $\left(24{ }^{\circ} \mathrm{C}\right.$ and $\left.75 \% \mathrm{RH}\right)$ for 6 months.

Detection from soil was performed both in the root area of infected and healthy plants (10 samples for each conditions and kiwifruit variety). For sampling, the litter-soil interface was discarded and only the first soil layer was sampled at a depth of $10 \mathrm{~cm}$. Psa presence was investigated also in 
rhizosphere soil. For this purpose, symptomatic plants were uprooted and the soil adhering to roots was analysed. Experiments were also performed in controlled conditions with the same soil samples sterilized and successively inoculated with Psa $\left(10^{9} \mathrm{CFU} \mathrm{g}^{-1}\right)$.

To evaluate Psa survival in water sources, 1-L samples were collected from different water sources (i.e. artificial basins inside the orchard, overflow water collector channels, rivers). Water was filtered by using a sterile nitrocellulose filter (pore $0.22 \mu \mathrm{m}, \varnothing 47 \mathrm{~mm}$ ). To concentrate Psa population, the used filter was collected and gently agitated $(50 \mathrm{rpm})$ for $5 \mathrm{~min}$ in $10 \mathrm{~mL}$ of sterile water. The resulting 100-fold concentrated suspension was plated and colony formation was assessed after $48 \mathrm{~h}$ of incubation at $27^{\circ} \mathrm{C}$.

Concerning non-host plants, the most common weed species present in kiwifruit orchards were sampled at bud break (BBCH 07), fruit set stages (BBCH 69) and harvest (BBCH 81). Six plants for each species were analysed at each phenological stage. Incidence was calculated by analysing 3-6 leaves for each plant. To calculate Psa population only positive samples were taken in account. The experiments in controlled conditions were performed only on the species where Psa was found in field conditions. The different plants were inoculated by spraying till run off with a Psa suspension of $2 \times 10^{7}$ cells $\mathrm{mL}^{-1}$. Plants were kept at $24{ }^{\circ} \mathrm{C}$ and $75 \% \mathrm{RH}$.

To determine the host tissues where Psa could overwinter, infected plants were selected at leaf fall. Successively, the plants were uprooted before bud break and the different organs were sampled to verify Psa presence and population. More in details, the following organs where analysed: dormant buds, the first $3 \mathrm{~cm}$ on each side of the bud, 1-year old canes, trunk and roots.

\section{Psa Recovery from Rain Splash}

The possible recovery of Psa from rain splash was performed according to the procedures described by Petriccione et al [32]. Briefly, Petri dishes containing nutrient agar supplemented with $3 \%$ sucrose (NSA) were attached to a plastic screen $(1 \mathrm{~m} \times 1 \mathrm{~m})$. Three plastic screens were joined together to intercept different wind directions. During rainfall, these screens supporting the Petri dishes without lids were positioned between the canopies of an A. chinensis var. deliciosa cv 'Hayward' orchard in Francolise (Campania region, southern Italy). After the rain, the Petri dishes were placed in an incubator at 23 $25^{\circ} \mathrm{C}$ for $48 \mathrm{~h}$. Levan-positive colonies were taken for Psa identification by previously described procedures [3, 33]. The assessment was performed during the vegetative season (from early April to early October).

\section{Statistical Analysis}

Data were analysed by one-way analysis of variance (ANOVA) followed by means separation with Fisher's least significant difference (LSD), using the STATISTICA ver. 7 software (StatSoft Inc., Tulsa, USA). Data were expressed as mean \pm standard error (S.E.). Differences were considered significant for $P \leq 0.05$ level. Bacterial growth in relation to temperature or relative humidity was assumed to fit a Gaussian curve. The curve was calculated with MyCurveFit online calculator (https://mycurvefit.com/). Comparison among percentages (e.g. incidence) was performed according to Marascuilo Procedure for $\chi^{2}=0.05$.

\section{Results and Discussion}

\section{Relative Importance of the Different Entry Points}

Epiphytic populations of Psa were detected on several plant organs including buds, leaves, twigs and flowers. Under experimental conditions, Psa penetration inside the host tissues was observed in intact leaves, flowers, lenticels, buds, leaf and fruit abscission scars and pruning cuts (Fig. 1).

The inoculation of leaves by CFBP7286-GFPuv produced leaf spots similar to the ones observed in natural conditions, but without a yellow halo surrounding the spots (Fig. 1.1 a). The average number of spots per leaf was generally higher in A. chinensis var. deliciosa (cv 'Hayward', 26 \pm 8 ) than in A. chinensis var. chinensis (average between cv. 'Hort16A' and 'Jintao', $15 \pm 6$ ). However, in A. chinensis var. deliciosa up to $35 \%$ of the spots presented a GFPuv-signal only inside the necrotic area suggesting the plant successfully contained the pathogen, preventing it from spreading beyond the necrotic spot. In A. chinensis var. chinensis, all leaf spots presented a bright green fluorescent edge indicating a successful spread of the pathogen beyond the necrotic area (Fig. 1.1 a). Once in the leaf apoplast, the pathogen could reach the veins (Fig. $1.1 \mathrm{a}$, c). The colonization of the vein may result in a systemic invasion of the plant via the migration inside vascular bundle of the leaf petiole (Fig. 1.1 b, d).

Despite the epiphytic colonization, plant organs may remain asymptomatic suggesting an epiphytic phase prior to the penetration inside the host tissues. Indeed, endophytic colonization occurs only after Psa epiphytic population exceeds the infection threshold that varies according to plant susceptibility. The infection threshold of leaves was calculated for the most diffused kiwifruit cultivars, estimating the epiphytic population of Psa at the time of apoplastic invasion. This value ranged from $10^{3}$ in the most sensitive cultivar to $2.5 \times$ $10^{4} \mathrm{CFU} \mathrm{g}^{-1}$ fresh weight (FW) in A. chinensis var. deliciosa (cv. 'Hayward') (Table 2). The infection threshold of leaves of male A. chinensis var. deliciosa (cv. 'Tomuri') plants was 

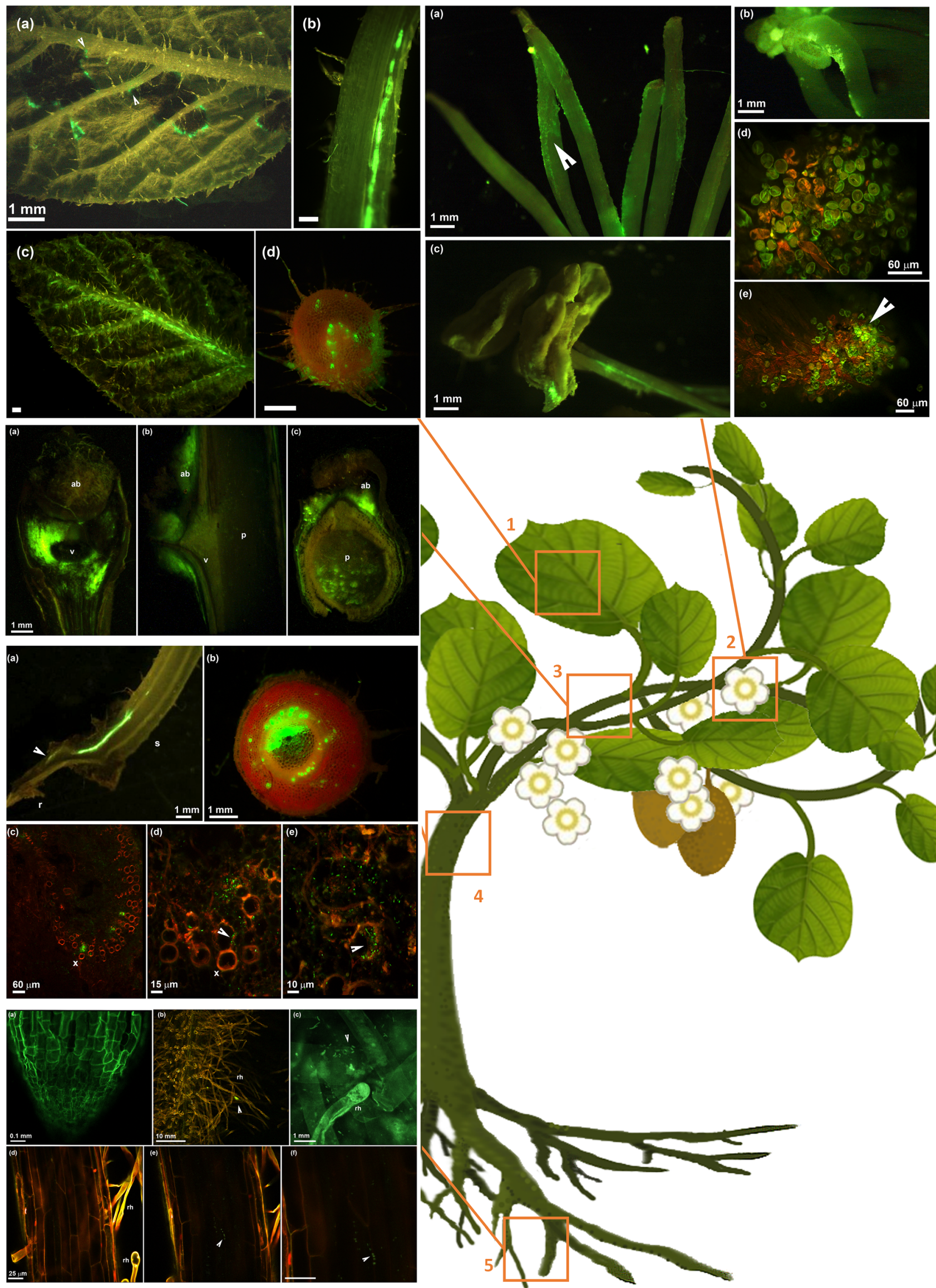

을 Springer 
Fig. 1 Different organs of kiwifruit plant colonized by Pseudomonas syringae pv. actinidiae expressing a green fluorescent protein (CFBP7286-GFPuv): (1) leaf infection, (2) flower infection, (3) infection of leaf abscission scar and colonization of developed bud, (4) migration inside xylem vessel, (5) colonization of roots. 1. Fluorescence stereomicroscope photographs of leaf infection in A. chinensis var. deliciosa (a-bd) and A. chinensis var. chinensis $(\mathbf{c})$. a Leaf showing angular necrotic spots. The necrotic spots are surrounded by a bright green edge caused by GFPuv-labelled Psa, indicating that the pathogen successfully evaded the necrotic area and the possible programmed cell death enacted by the host to contain the pathogen spread. The angular spots can cover leaf lateral veins, suggesting the possible entry of the pathogen into the vascular system. b Migration of Psa inside the leaf petiole, leading to a systemic infection of the host plant. $\mathbf{c}$ A. chinensis var. chinensis young leaf infected by GFPuv-labelled Psa. Even in absence of leaf symptoms, the central leaf vein was colonized. $\mathbf{d}$ Transversal section of a leaf petiole showing the xylem vessels fully colonized by GFPuv-labelled Psa. The cortical parenchyma and the epidermis were also colonized, suggesting that Psa migration from the leaves to the shoots may occur both inside the petiole and along it by epiphytic growth. In all panels, the measure bar is $1 \mathrm{~mm}$. 2. Flower infection in A. chinensis var. deliciosa $(\mathbf{a}, \mathbf{b})$ and $A$. chinensis var. chinensis (c, d, e). a Fluorescence stereomicroscope photograph of stigmas and styles colonized by GFPuv-labelled Psa. The pathogen migrates epiphytically along the style by forming a biofilm covering the surface of the style (arrow). b Fluorescence stereomicroscope photograph showing the epiphtytic colonization of stigmas inoculated by pollen contaminated with by GFPuv-labelled Psa. c Fluorescence stereomicroscope photograph of dehiscent anthers colonized by GFPuv-labelled Psa. The pathogen colonized also the pedicels. d, e Confocal laser scanning micrograph showing stigmas coated by pollen grains contaminated with by GFPuv-labelled Psa. The arrow indicates an area were a successful colonization of the stigma by the pathogen occurred. The measure bar is indicated in each panel. 3. Fluorescence stereomicroscope photograph of A. chinensis var. deliciosa leaf abscission scars infected by GFPuvlabelled Psa. a photograph of the abscission scar taken from above. The whole area corresponding to the abscission scar is characterized by a bright green signal due to pathogen colonization; ab: axillary bud, v: vascular bundle corresponding the junction between the leaf petiole and the lignified shoot. b Longitudinal and $\mathbf{c}$ transversal sections of the leaf scar. The tissues surrounding the scar show a bright green signal. The axillary bud is also colonized; p: pith. In all panels, the measure bar is $1 \mathrm{~mm}$. 4. Systemic colonization of Actinidia plants via migration inside the xylem vessels. a Fluorescence stereomicroscope photograph of a longitudinal section of a young $A$. chinensis var. deliciosa seedling approximately $5 \mathrm{~cm}$ tall. Inoculation was performed on the shoot tip. Psa colonization is concentrated in the vascular bundle inside the main shoot (s) up to the taproot (r). b Fluorescence stereomicroscope photograph of a transversal section of the main stem of a young $A$. chinensis var. deliciosa seedling. Psa heavily colonized the primary and secondary xylem vessels and pith. Sporadic presence of Psa is also visible in sieve elements and sclerenchyma fibres in the cortex. c-d confocal laser scanning micrographs showing xylem vessels $(\mathrm{x})$ colonized by Psa. Each green rod corresponds to a pathogen cell. The arrow indicates Psa cell attached to the internal wall of the xylem vessels. The measure bar is indicated in each panel. 5. Confocal laser scanning micrograph of Actinidia roots. a Uninfected root tip. b Root hairs. The arrow indicates a Psa microcolony growing on the root surface. $\mathbf{c}$ Magnification of root hairs colonized by Psa. Rh: root hair. Each green rod corresponds to a pathogen cell. d-ef Micrograph of a fine root surrounded by root hairs. $\mathbf{d}$ External surface of the root without the presence of Psa; e internal tissues inside the root where Psa microcolonies are visible; $\mathbf{f}$ magnification of Psa microcolonies inside the root. In all panels, the measure bar is $25 \mu \mathrm{m}$
Table 2 Pseudomonas syringae pv. actinidiae infection thresholds calculated for $A$. chinensis var. chinensis and A. chinensis var. deliciosa cultivars. Infection threshold values are expressed as $10^{\mathrm{x}} \mathrm{CFU}$ $\mathrm{g}^{-1}$ FW. X values marked with the same letter do not differ according to Fisher's LSD test $(P \leq 0.05)$. Average $\pm \mathrm{SE}$ are reported

\begin{tabular}{lll}
\hline Species & Cultivar & Value of $x$ \\
\hline A. chinensis var. chinensis & 'Zesy002' & $4.2 \pm 0.2 \mathrm{a}$ \\
A. chinensis var. chinensis & 'Hort16A' & $3.2 \pm 0.2 \mathrm{~b}$ \\
A. chinensis var. chinensis & 'Jintao' & $3.0 \pm 0.3 \mathrm{~b}$ \\
A. chinensis var. deliciosa & 'Hayward' () & $4.4 \pm 0.4 \mathrm{a}$ \\
A. chinensis var. deliciosa & 'Tomuri' (ठ) & $3.3 \pm 0.3 \mathrm{~b}$ \\
\hline
\end{tabular}

significantly lower than that of female (cv. 'Hayward') ones (Table 2). In controlled conditions, the infection threshold was generally reached in 6-24 h post inoculation. Experimental inoculation of leaves by spraying till run-off Psa $\left(10^{6} \mathrm{CFU} \mathrm{mL}^{-1}\right)$ resulted in $(65 \pm 6) \%$ of invasion of $A$. chinensis var. chinensis and $(58 \pm 7) \%$ of $A$. chinensis var. deliciosa leaf petiole, indicating a successful systemic migration of the pathogen.

The need for Psa to reach a population threshold before infection takes place, can explain the isolation of Psa in asymptomatic tissues [11].

Generally, the plant surface is thought to be a hostile environment for microorganisms with limited nutrients, drastic and rapid variations in temperature and humidity even during a single day, direct exposure to damaging UV irradiation, and competition and/or antagonism from other epiphytes [34, 35]. On the other hand, Actinidia leaves are typically covered with a dense layer of trichomes (Fig. 2) which may play an important role in the infection process [10], by creating a favourable and humid micro-environment and protecting the pathogen from adverse condition such as UV light, desiccation, pesticide sprays etc. In addition, epiphytic bacteria like Psa can live in large aggregates or microcolonies which can form or be part of a biofilm on the leaf surface, presumably to better resist environmental stresses, like other Pseudomonas species [36]. Indeed, on leaf surface, Psa microcolonies were primarily localized at the base of uniseriate and stellate trichomes (Fig. 3 b,c). Different Actinidia species present different types and densities of trichomes [37]. On the abaxial leaf surface, multicellular stellate hairs, either petiolate or not, are the most common type of trichome in both A. chinensis var. chinensis and $A$. chinensis var. deliciosa leaves. Similarly, in other plant species, Pseudomonas syringae pv. syringae bacterial cells, rather than being randomly distributed over the leaf surface, form aggregates associated with leaf structures, such as veins and particularly glandular trichomes $[38,39]$. It has been observed that glandular trichomes offer optimal conditions for microbial growth due to their ability to retain water [40] and secrete a diversity of chemical compounds, including sugars, proteins, oils and secondary compounds [41, 42]. Moreover, 

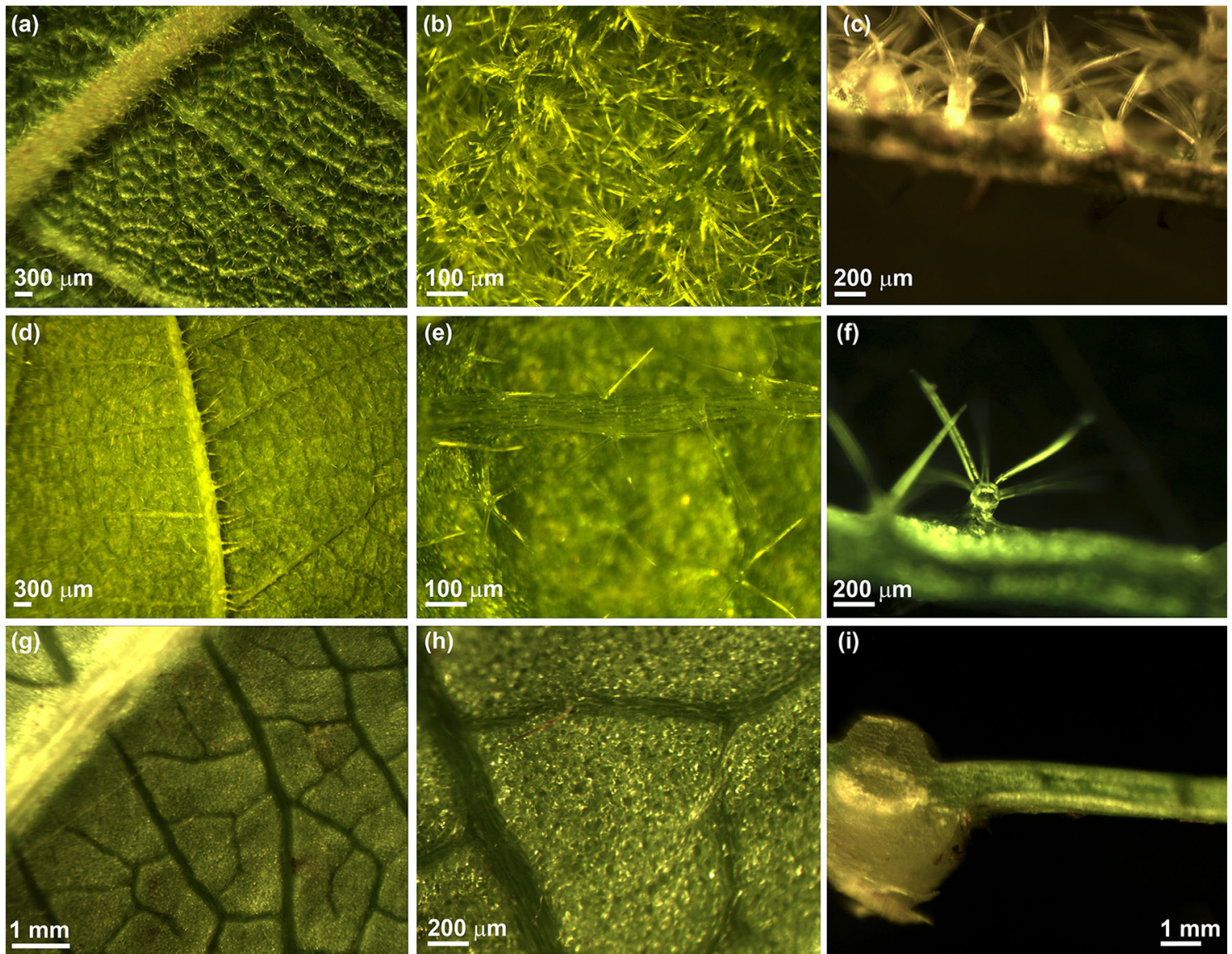

Fig. 2 Leaf structure in different Actinidia species: A. chinensis var. chinensis (a, b and $\mathbf{c})$, A. chinensis var. deliciosa (d, e and $\mathbf{f})$ and A. arguta (g, h and $\mathbf{i})$. a Abaxial surface of A. chinensis var. chinensis leaf showing a lateral vein. b Higher magnification of A. chinensis var. chinensis leaf surface showing a dense layer of stellate trichomes. $\mathbf{c}$ Transversal section of a A. chinensis var. chinensis leaf. The abaxial surface is on top of the image, and it is characterized by petiolate stellate trichomes. On the adaxial surface, uniseriate multicellular

plant trichomes are also generally fragile and plant pathogenic bacteria can enter hosts through the open bases or broken stalks of damaged trichomes [43]. In the presence of free water, $P$. syringae pv. tomato residing on or near trichome bases have been shown to readily invade tomato fruit through these openings and multiply inside the broken trichome bases [44]. Psa has been observed to invade kiwifruit leaves via damaged trichomes [10,13].

Therefore, the density of trichomes on the abaxial leaf surface may contribute to the different susceptibility observed in kiwifruit species and cultivars. Indeed, A. chinensis var. chinensis cultivars, that are more susceptible to infection, also present a higher trichome density in comparison to A. deliciosa (Fig. 2). Moreover, both in A. chinensis var. chinensis and var. deliciosa, young leaves present a higher trichome density than the older and more resistant (see below) leaves. Finally, in resistant species, such as A. arguta, trichomes are almost absent (Fig. 2). trichomes are visible. d Abaxial surface of A. chinensis var. deliciosa leaf showing a lateral vein. e Trichome distribution in A. chinensis var. deliciosa abaxial leaf surface showing stellate trichomes. f Transversal section of an A. chinensis var. deliciosa leaf. g Abaxial surface of an A. arguta leaf showing a lateral vein. $\mathbf{h}$ Higher magnification of the abaxial surface of an A. arguta leaf characterized by the absence of trichomes. i Transversal section of $A$. arguta leaf. The abaxial surface is on the top

After the epiphytic growth, as soon as the leaf is exposed to few hours of leaf wetness, penetration inside the host occurs via stomata (Fig. 3d, f). Under experimental inoculation, the infection through the stomata was responsible for the majority of leaf spots, being several stomata per leaf colonized by the pathogen (Fig. 3a).

Leaf wetness is an essential pre-requisite for infection since it provides a continuum between the leaf surface colonized by the pathogen and the stomatal chamber [45]. Invasion via stomata is a common mechanism in several plant pathogenic bacteria [39]. However, stomata also represent the first line of defence of the plant innate immune system, and plants have evolved a mechanism to close stomata upon sensing microbe-associated molecular patterns [46]. To overcome these defences, different Psa biovars developed different accessorial virulence factors, such as coronatine $[47,48]$ or ethylene [5], that promote stomata opening. 
Fig. 3 Kiwifruit leaves (a-f) and lenticels $(\mathbf{g}-\mathbf{h})$ colonized by Psa CFBP7286-GFPuv (a, c, e, f) or CFBP7286-DsRED (b, d, h). a

Fluorescence stereomicroscope photograph of the abaxial surface of an A. chinensis var. deliciosa leaf. Several infected stomata are highlighted as bright green fluorescent spots. The arrow indicates a leaf lesion producing a drop of bacterial exudate. Stomata are highlighted with an 's'. b

Uniseriate multicellular trichome colonized by Psa. Each red rod is a bacterial cell. Psa forms microcolonies at the base of the trichome. $\mathbf{c}$ Abaxial surface of a A. chinensis var. chinensis leaf. The base of several petiolate stellate trichomes is colonized by Psa CFBP7286-GFPuv (bright green signal). d-e Confocal laser scanning (CLSM) micrographs of A. chinensis var. deliciosa and A. chinensis var. chinensis (f) showing colonization of stomata by Pseudomonas syringae pv. actinidiae. To visualize the host colonization in vivo, the strains CFBP7286-DsRED (d) or CFBP7286-GFPuv (e, f), expressing a red or green fluorescent protein, were used. In micrograph (d) each red rod is a single pathogen cell; in (e) and (f), Psa cells are visualized as green rods.

Unless specified, measuring bars in the same raw have the same length. g Confocal laser scanning micrograph of a healthy lenticel of a 2-week-old $A$. chinensis var. chinensis shoot. The lenticel surface is characterized by stomatalike structure indicated by the arrow. In the central part of the lenticel, a dark micro lesion, due to the swelling of lenticel in high humidity conditions, is also visible. $\mathbf{h}$ Lenticel infected by Psa CFBP7286-DsRED. Each red spot is a bacterial microcolony. Psa colonize the lenticel surface and it is associate to a microlesion due to lenticel swelling (arrow)
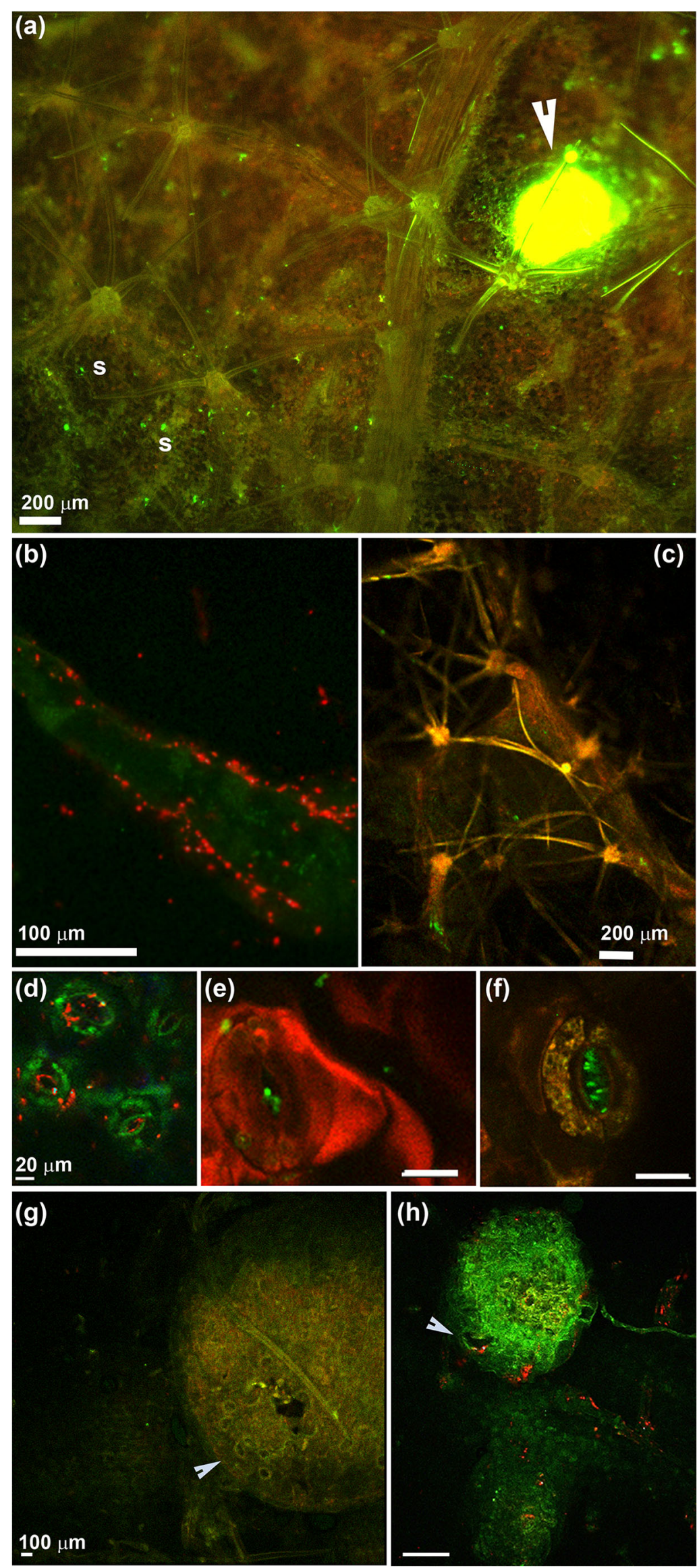
Finally, leaf spots, under conditions of relative humidity exceeding $80 \%$, can also produce bacterial exudate (Fig. 3a).

Together with leaves, flowers are the other primary site of infection of Psa $[15,49,50]$. This bacterium can colonize both female (Fig. 1.2 a, b) and male (Fig. 1.2 d, e) Actinidia flowers, causing flower browning and fall, and systemic invasion of the host plant, eventually leading to its death [50]. On female flowers, Psa initially colonize the stigma, which provides a nutrient-rich and humid environment allowing a fast growth of the pathogen. From the stigma, Psa migrates along the style till the nectar cup (Fig. 1.2 a). Systemic penetration into the flower can occur either from the stigma or via the nectarthodes [50]. Psa is often vectored to stigma by contaminated pollen (Fig. 1.2 b). Experimental inoculation of flowers with Psa $\left(10^{6} \mathrm{CFU} \mathrm{mL} \mathrm{mL}^{-1}\right)$ resulted in $(75 \pm 5) \%$ of systemic invasion of $A$. chinensis var. chinensis and $(53 \pm 6) \%$ of A. chinensis var. deliciosa female flowers. Incidence of systemic invasion of male flowers was, in both species, approximately $60 \%$. Infection threshold on the flowers of the different species has not been yet estimated. However, in the first $6 \mathrm{~h}$ after inoculation with low Psa dosage $\left(10^{4} \mathrm{CFU} \mathrm{mL}^{-1}\right)$, Psa population ranged between $(3.0 \pm 1.6) \times 10^{5} \mathrm{CFU}$ and $(2.4 \pm 1.4) \times 10^{6} \mathrm{CFU}$ per flower in A. chinensis var. deliciosa and $A$. chinensis var. chinensis, respectively. These population values are close to the carrying capacity of flowers and thus they most likely exceed the flower infection threshold [50].

At bud break, Psa can systemically migrate from the overwintering organs to swelling bud. In male plants, the internal contamination of flower buds may lead to colonization of anthers (Fig. 1.2 c) which will produce contaminated pollen [50]. Moreover, several studies showed that Actinidia spp. pollen or commercial pollen preparations can be contaminated by Psa [10, 51-55]. Contaminated pollen and pollen-mediated flower contamination (Fig. $1.2 \mathrm{~d}, \mathrm{e}$ ) is one of the main infection pathways in field conditions [50].

In experiments on buds, colonization of cortical tissues of both closed and open buds was observed and Psa population increased with the bud evolution, as buds developing a shoot include a 100-fold higher Psa population than swelling buds (Fig. 4a). Bud colonization can occur both from internal migration from overwintering organs or from external colonization. Experimental inoculation performed during advanced bud swelling (BBCH 03) by wetting buds with a Psa suspension $\left(10^{7} \mathrm{CFU} \mathrm{mL} \mathrm{mL}^{-1}\right)$ resulted in $(70 \pm 13) \%$ and $(77 \pm 10) \%$ bud endophytic colonization in $A$. chinensis var. deliciosa and A. chinensis var. chinensis, respectively.

Actinidia lenticel morphology evolves and changes through different phenological phases, changing from a cluster of stomata to a semi-impermeable tissue. Epiphytic colonization of lenticels was frequently observed, and in young hydrated lenticels, Psa primarily localized around microwounds or stomata-like structure (Fig. $3 \mathrm{~h}, \mathrm{~g}$ ). However, successful inoculation via lignified lenticels was achieved only by placing for 3 days a Psa $\left(10^{8} \mathrm{CFU} \mathrm{mL}^{-1}\right)$ imbibed cotton wool around the trunk. Under experimental inoculation, lenticel colonization allowed the invasion of the host tissues (Fig. 4b and Supplementary Fig. S1). The maximal incidence of endophytic colonization after inoculation of lenticels was $(50 \pm 6) \%$ and $(75 \pm 9) \%$ in A. chinensis var. deliciosa and A. chinensis var. chinensis, respectively. Although it was not possible to elucidate the effective risk of penetration via lenticels in natural conditions, experiments performed on lignified lenticels suggest they may be of limited importance as Psa entry points.

After the initial spread occurring in spring via the leaf and flower disease cycles, another important step of the disease cycle leading to systemic colonization occurs in autumn. Indeed, in this season, leaf and fruit abscission scars and pruning cuts represent important entry points for the pathogen (Fig. 1.3). In A. chinensis var. deliciosa, colonization of leaf scars was also possible even 15 days after leaf detachment (either natural or mechanical) (Fig. 4c). In comparison to natural abscission scars, the mechanically induced ones initially host a higher Psa population. This observation may suggest that the abscission layer formed during the onset of natural leaf senescence may at least partially reduce the risk of Psa colonization. Upon experimental inoculation, the average incidence of contamination of natural leaf scars was $(25 \pm 3) \%$, with no substantial differences during the time of observation.

Similar results were observed for pruning cuts, as wounds remained receptive even 1 month after cutting (Fig. 4d). Incidence after inoculation of pruning cuts was initially $80 \%$ and decreased to $70 \% 28$ days after cutting. Experiments performed on $A$. chinensis var. chinensis showed similar results suggesting that $A$. chinensis var. deliciosa and A. chinensis var. chinensis have similar susceptibility concerning pruning cuts (Supplementary Fig. S1).

Inoculation of Actinidia by roots dipping in a Psa suspension, resulted, in axenic conditions, in colonization of root hairs, where a sporadic occurrence of Psa microcolonies was observed starting from 1 day after inoculation (Fig. 1.5 b, c). However, a successful endophytic colonization of the plant after root inoculation was not observed up to the end of the experiments (30 days after inoculation). On the other hand, an endophytic presence of Psa inside the roots of plants inoculated in the aboveground organs (e.g. leaves and flowers) was observed (Fig. $1.5 \mathrm{~d}, \mathrm{f}$ ).

A critical phase of the life cycle of Psa is its ability to endophytically migrate from the leaves to shoots and canes via apoplast $[5,10,13]$. This systemic invasion of the plant may determine the rapid death of plants [10]. Indeed, once inside the host's tissues, Psa can migrate systemically to different organs. Migration occurs preferentially through xylematic vessels (Fig. 1.4), where Psa is often found attached to the vessels wall. Moreover, plugging of xylem vessel was often observed [13]. Sporadic presence of Psa was also found 

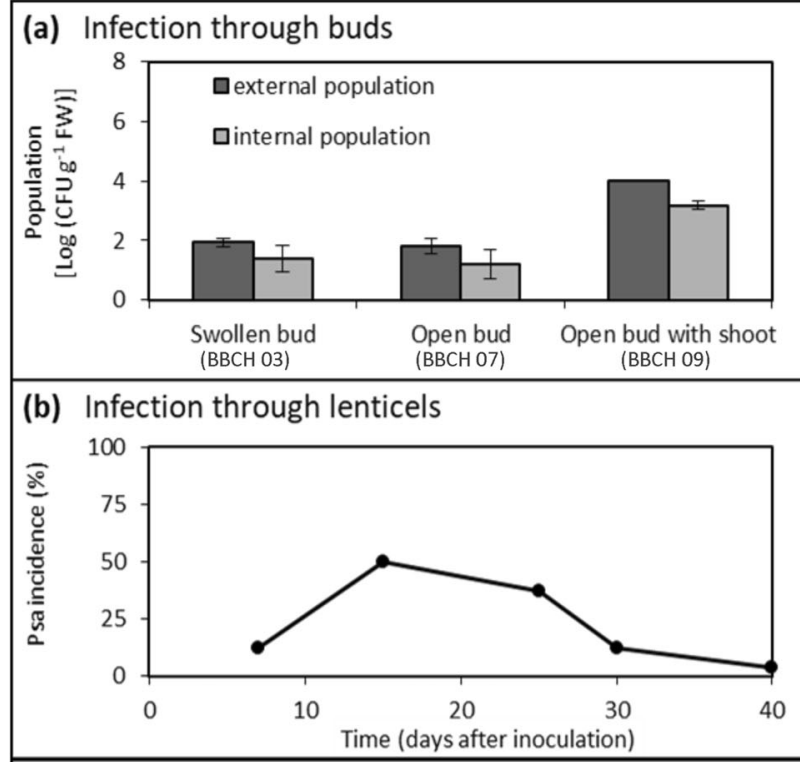

(c) Infection through leaf scars

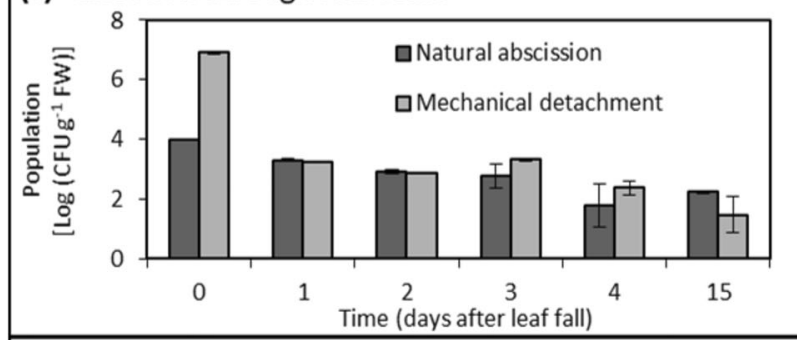

(d) Infection through pruning wounds

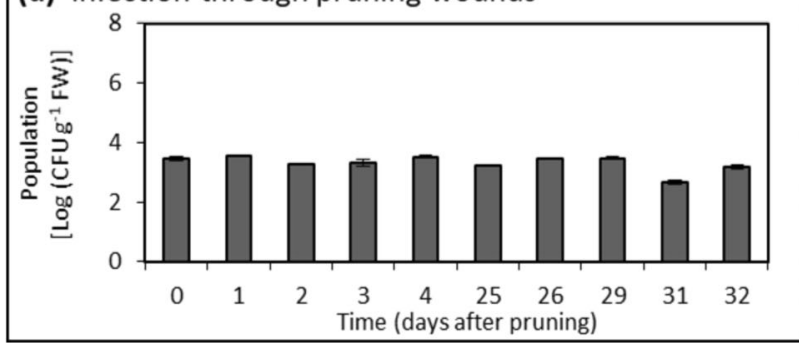

Fig. 4 Pseudomonas syringae pv. actinidiae population in A. chinensis var. deliciosa plants after infection via different entry points. a Epiphytic and endophytic Psa population in buds at different phenological stages: swollen (BBCH 01), open (BBCH 07) and with emerging leaves (BBCH 09) measured in the first 2 weeks. Experiments were performed in screenhouse without controlled environmental conditions. Closed (BBCH 00) or swollen (BBCH 03) [30] buds were inoculated by applying for $24 \mathrm{~h}$ a cotton plug soaked in bacterial suspension. Epiphytic and endophytic population were assessed 10 days after inoculation. Experiments was performed on five replicates of 6 bud each. b Incidence of Psa endophytic population in kiwifruit tissues after inoculation of lenticels. The experiment was performed on five replicates of four lenticels each. $\mathbf{c}$ Endophytic Psa population after inoculation of leaf abscission scars. Both natural abscission scars (autumn) and

in sieve elements and schlerenchymatic fibres in the shoot cortex. Psa can migrate both acropetally and basipetally, moreover, Psa can go beyond branching node moving equally in the different directions (Fig. 4e). The migration rate was (e) Migration rate from infection point

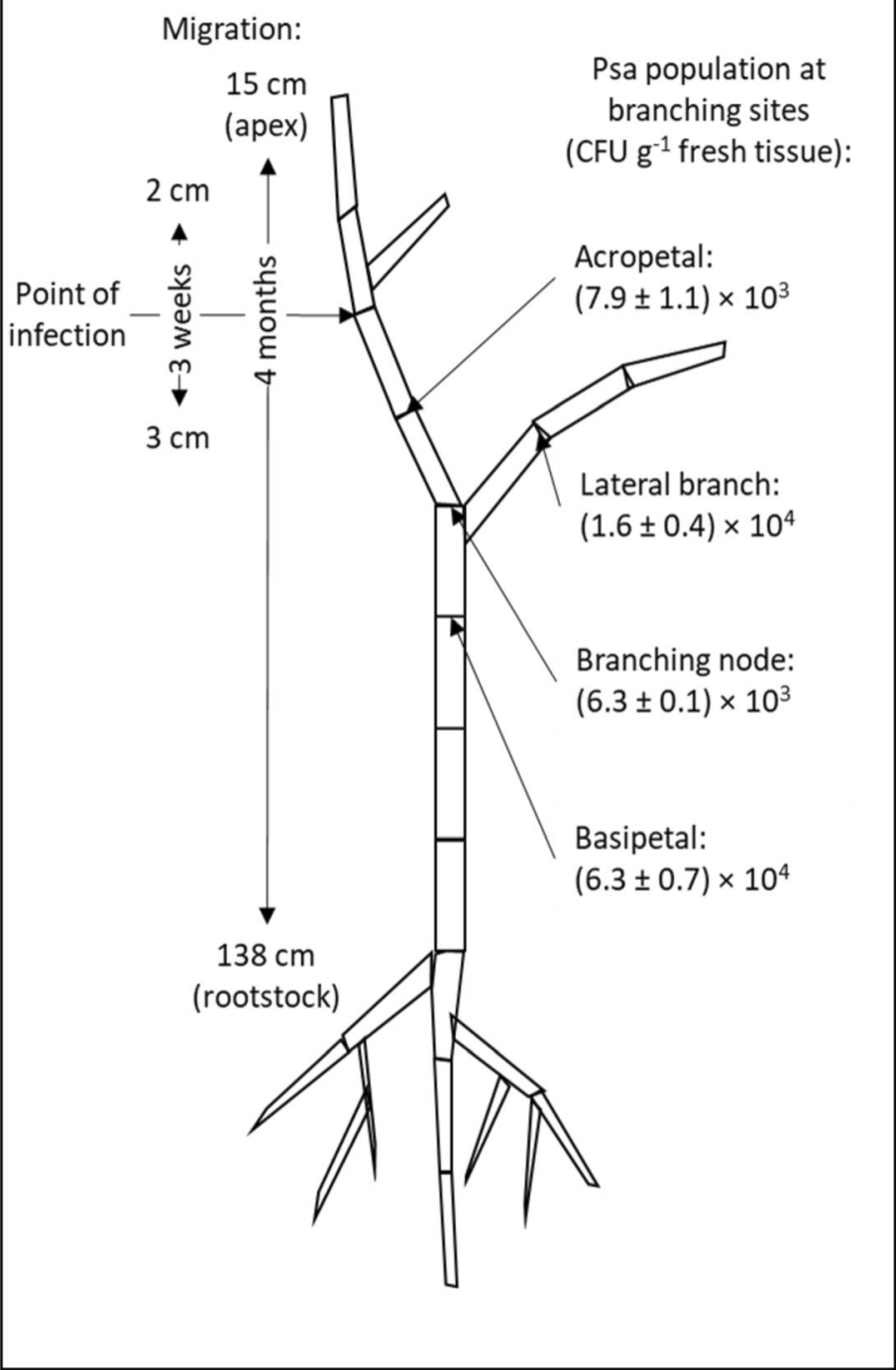

mechanically induced ones (late summer) were inoculated. Experiment was performed on six replicates of six scars each. d Psa endophytic population in 3-cm-long wood samples after inoculation of pruning cuts with a Psa suspension (CFBP7286 at $10^{7} \mathrm{CFU} \mathrm{mL}^{-1}$ ). To verify the time needed for a complete healing of the pruning cuts, inoculation was performed up to 32 days after the cutting and the re-isolation occurred after 10 days. Experiments was performed on five replicates of three pruned canes per each timepoint. e Scheme of the sampling of A. chinensis var. deliciosa potted plant infected with Pseudomonas syringae pv. actinidiae, in order to evaluate the rate of migration of bacteria in the plant. Psa population was determined in different parts of the plant 3 weeks or 4 months after inoculation in a single point. Average endophytic population in the different branching node or section is also reported. Each plant section was $10 \mathrm{~cm}$ long. In all panels, average \pm standard error is reported

evaluated in A. chinensis var. deliciosa and A. chinensis var. chinensis after stab-inoculation of a single shoot of 1-year old potted plants. Previous studies demonstrated that the migration rate negatively correlated with plant resistance [56]. In 
our experiments, migration rate correlated only weakly with the host susceptibility. Indeed, 3 weeks after inoculation acropetal and basipetal migration were 2 and $3 \mathrm{~cm}$, respectively both in A. chinensis var. chinensis and A. chinensis var. deliciosa. However, endophytic Psa population at the same distance from the inoculation points were generally higher in A. chinensis var. chinensis in comparison with A. chinensis var. deliciosa. In 4 months, the furthest migration upward reached $14.5 \mathrm{~cm}$ (till the apical bud), whereas downward, it reached $138 \mathrm{~cm}$ (Fig. 4e). Furthermore, Psa completely colonized the roots reaching the most distant $(142.5 \mathrm{~cm})$ ones from infection point, passing beyond the grafting union.

While the exact mechanisms of migration have not been yet elucidated, both acropetal and basipetal movement was observed. Xylematic flow may easily be invoked to explain the translocation toward transpiring leaves, since Psa is found within xylem vessels (Fig. 1.4) $[13,14]$. However, the plant is able to restrict bacterial migration through the xylem to some degree, by producing tyloses [13]. A local increase of hydrostatic pressure, caused by the release of exopolysaccharides and other water-attracting solutes [57-60], is commonly considered responsible for the outbreak of bacterial exudates from the bark, but might as well contribute to bacterial migration in the apoplast as mass flow. Indeed, for several bacterial pathogens the systemic migration within the host plant is dependent on exopolysaccharides production [58, 60]. Finally, active bacterial chemotaxis may, at least partially, facilitate the diffusion of Psa within the host tissues. The rate of endophytic colonization has been shown to be dependent on the relative humidity [61]. Thus, conditions with high RH favour both the infection process and the migration inside the host plant.

\section{Host Susceptibility}

Psa epiphytic populations were higher in A. chinensis var. chinensis cultivars than in A. chinensis var. deliciosa (Fig. 5a). However, the growth of epiphytic population showed a similar trend in all the A. chinensis var. chinensis cultivars regardless of their susceptibility. Similar results were observed also for the endophytic growth of the pathogen (Fig. $5 b)$.

The percentage of dead plants 4 months after infection, the migration of Psa inside the host tissues and Psa endophytic population follow a similar trend and correlate with host susceptibility observed in orchard conditions (Fig. 6). On the other hand, early symptom development, such as the formation of necrotic spots on leaf, often does not correlate with plant susceptibility. Indeed, in field conditions, 'Hort16A', the most sensitive cultivar, may present a much lower percentage of leaf spots than $A$. chinensis var. deliciosa, which is, among the commercial cultivar, the most tolerant.
In our experiments, the dynamics of Psa endophytic growth results as the most reliable parameter to assess plant susceptibility.

Additional experiments were also performed to evaluate the susceptibility of $A$. arguta, a minor, but important Actindia species. In stab-inoculation experiments, all the A. arguta cultivars showed less severe symptoms than A. chinensis var. deliciosa and A. chinensis var. chinensis, most notably 3 weeks after inoculation (Fig. 7). Moreover, A. arguta plants showed the lowest Psa endophytic population and migration distance inside the tissues (Fig. 7). These findings confirm the results obtained by Cotrut and colleagues [63]. Psa is rarely found in commercial orchards of $A$. arguta and, when it is found, its economic consequences are negligible [64].

The most important cultivated kiwifruit varieties can be listed in order of increasing susceptibility as follows:

- A. arguta - Different cultivars.

- A. chinensis var. deliciosa - 'Hayward'.

- A. chinensis var. chinensis - 'Zesy002'.

- A. chinensis var. chinensis - 'Jintao'.

- A. chinensis var. chinensis - 'Hort16A'.

Phenological factors such as differences in flowering times between A. chinensis var. chinensis and A. chinensis var. deliciosa [29] could also be significant, and they have been observed to generate differences to insect susceptibility [29]. Xylem tyloses were observed more frequently in A. chinensis var. deliciosa than in A. chinensis var. chinensis infected xylem [13]. Biochemical factors contributing to resistance have been largely understudied, however, differences in the expression of pathogenesis-related proteins and enzymes of the phenylpropanoid pathway, and in peroxidase and NAD $(\mathrm{P}) \mathrm{H}$ oxidase activities may relate to the different sensitivity of Actinidia spp. to Psa. In fact, these responses were more intensely stimulated by the plant defence inducer acibenzolar-Smethyl, in A. chinensis var. deliciosa than in A. chinensis var. chinensis [65].

\section{Influence of Environmental Conditions on the Infection Process of $P$. syringae pv. actinidiae and Summer Latency}

The bacterial growth rate in planta was calculated before reaching $\log$ phase, either in a range of $\mathrm{RH}$ at a fixed temperature $\left(24{ }^{\circ} \mathrm{C}\right)$, or at different temperatures at $75 \% \mathrm{RH}$. To calculate the growth rate, data obtained on three $A$. chinensis var. chinensis and one A. chinensis var. deliciosa cultivars were averaged.

Psa epiphytic and endophytic growth resulted highly influenced by temperature with an optimal thermal range between 21 and $25^{\circ} \mathrm{C}$ (Fig. 8a). The highest observed growth rate occurred for both epiphytic and endophytic phase at $21{ }^{\circ} \mathrm{C}$. 
Fig. 5 Pseudomonas syringae pv. actinidiae epiphytic (a) and endophytic (b) growth in A. chinensis var. chinensis ('Zesy002', 'Hort16A' and 'Jintao') and A. chinensis var. deliciosa ('Hayward') leaves. The data are the average growth at different combinations of temperature and relative humidity $\left(16,21,24,30^{\circ} \mathrm{C}\right.$ at $65 \% \mathrm{RH}$, $24^{\circ} \mathrm{C}$ at 65,75 and $90 \% \mathrm{RH}$ at $24^{\circ} \mathrm{C}$ ). Average \pm standard errors are shown

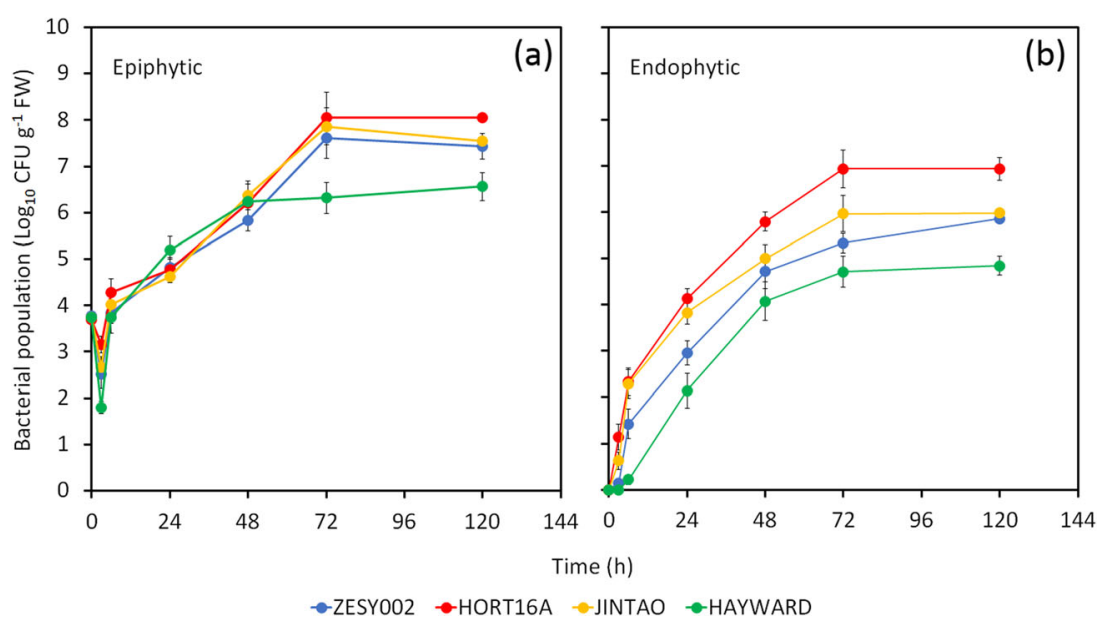

The predicted optimal temperature was $21^{\circ} \mathrm{C}$ and $24^{\circ} \mathrm{C}$ for epiphytic and endophytic growth, respectively.

Concerning relative humidity, the highest epiphytic growth was observed at $65 \%$, whereas, for endophytic growth the optimal humidity was over $75 \%$ (Fig. 8 b). The predicted optimal RH was $60 \%$ and $80 \%$ for epiphytic and endophytic growth, respectively. Moreover, humidity significantly influenced the maximum population size reached by the pathogen in the endophytic, but not in the epiphytic phase (Fig. 8b).

The dynamic of population growth showed a similar trend in the different cultivars, but it was faster in the more susceptible ones (i.e. 'Hort16A' and 'Jintao') (supplementary Fig. S2 and S3).

The environmental conditions also influence the disease incidence and severity in field conditions. Experiments conducted in three consecutive years (2013-2015) in three locations suggest that leaf wetness and temperature are the two main drivers of primary symptom occurrence and development (Fig. 9). Symptom development concentrates in the spring (April-May), between 7 and 70 days after bud break, as no further increase in leaf spots is observed from late June on. In this period, the average daily temperature was about $18.4 \pm 3.7^{\circ} \mathrm{C}$ and symptoms occurred at the same time of periods of leaf wetness. Generally, symptoms were observed when leaf wetness in the previous 3 days was lasting more than $4.5 \mathrm{~h}$ per day. At the increase of temperature around 22.3 $\pm 2.2{ }^{\circ} \mathrm{C}$, symptom occurrence ceased also in presence of leaf wetness periods. Finally, the correlation between temperature and relative humidity breaks down during temperature falls below a daily average of approximately $15{ }^{\circ} \mathrm{C}$. During summer, the progress of disease incidence and severity is arrested, most probably as a consequence of temperature, rather than of leaf ontogenetic resistance. In fact, even though older leaves tend to be less susceptible (Fig. 10a, b) the disease progression in field conditions stopped also in 1- and 2-week old leaves at the beginning of June, corresponding to an increase of average temperature above $22^{\circ} \mathrm{C}$ (Fig. 10c). Moreover, in experiments carried out with 3-week-old sentinel plants, placed every week in infected orchards, incidence and population of Psa were correlated, and were promoted by extended leaf wetness. However, similarly to field conditions, symptoms only formed in spring and early summer (supplementary Fig. S4). Symptoms (exudates, water-soaked leaf spots) may as well appear in autumn after frost events [66].

\section{Spread of the Disease inside the Orchard (Insect-mediated Spread, Human Spread, Wind and Rain Splashing)}

Since Psa has the ability to penetrate into the host plant tissues through multiple entry points, many agents may contribute to its spread in the orchard from the sources of inoculum. Agricultural practices are one main factor, since, on the one hand, they create or facilitate pathways for pathogen infection and are applied systematically on every single plant in the orchard. On the other hand, the chance of infection can be reduced by optimizing agricultural practices and controlling the main risk factors. While the role of clothes and vehicles is negligible [67], soil particles and agricultural tools can easily spread Psa within and among orchards. Thus, agricultural practices should keep the initial inoculum as low as possible and be performed when the pathogen is least active to restrict its population growth.

Pruning, for instance, may allow the pathogen to be carried through cutting tools and to be directly injected into open wounds. Thus, it was observed that winter pruning, when the plant is completely dormant, is associated to the lowest disease incidence in the following season, while late pruning at bleeding sap stage results in the highest incidence. In addition, intra-row spread prevailed over inter-row spread, suggesting that close distance of infected and recipient tissues and/or temporal vicinity of human intervention are the main determinants of the chance of infection [62, 67, 68]. Notably, short pruning is also not reliable for curative purposes, to 

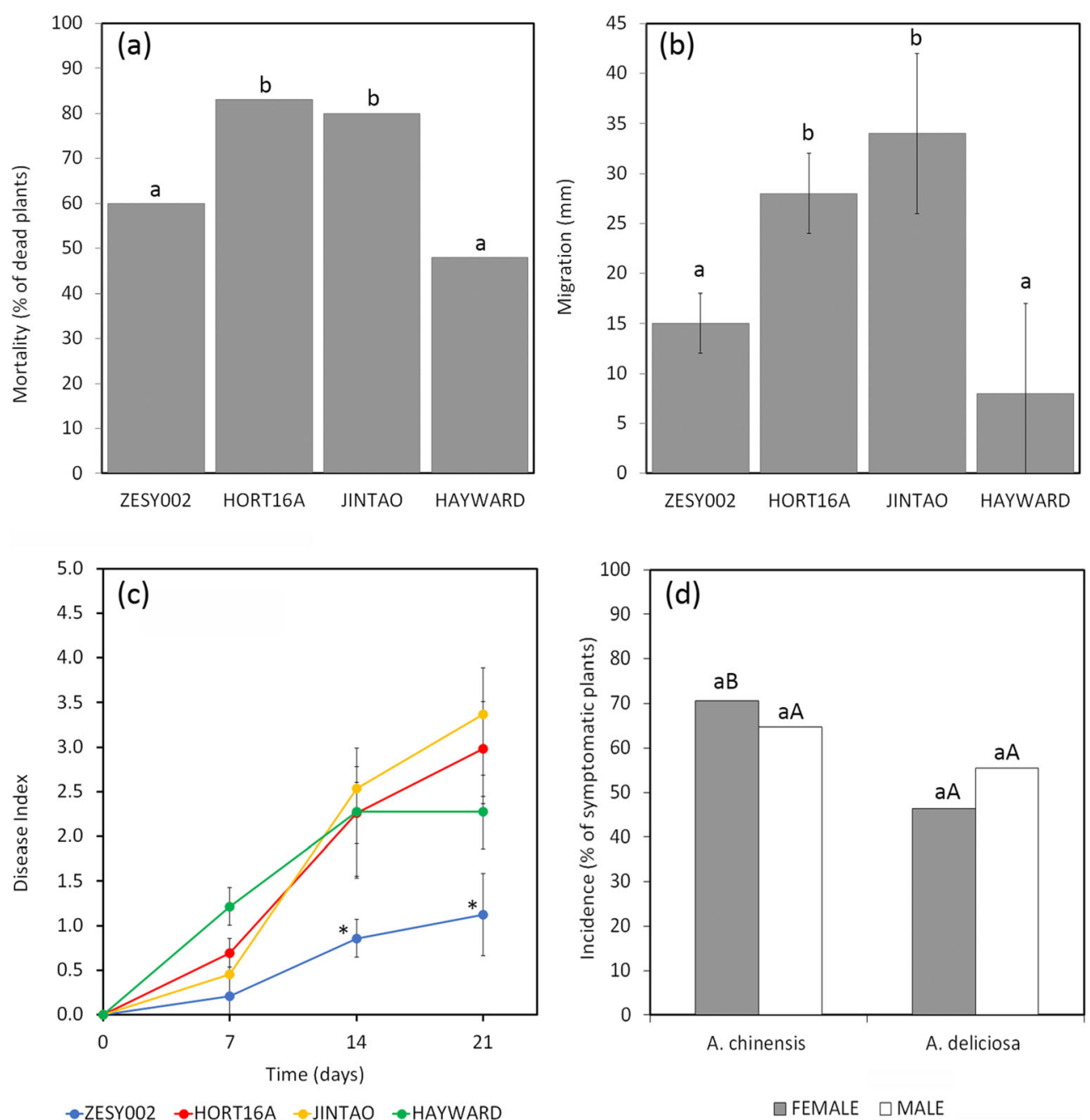

Fig. 6 Cultivar susceptibility to Pseudomonas syringae pv. actinidiae in A. chinensis var. chinensis ('Zesy002', 'Hort16A' and 'Jintao') and A. chinensis var. deliciosa ('Hayward') plants. a Percentage of infected plants dying within 4 months from inoculation. Columns labelled with different letters are significantly different according to Marascuilo procedure $\left(\chi^{2}=0.05\right)$; b average length of the migration of Pseudomonas syringae pv. actinidiae (CFBP7286-GFPuv) inside the plant host tissues, 3 weeks after inoculation; columns labelled with different letters are significantly different according to Fisher's LSD test $(P \leq 0.05)$. c Disease index calculated during the first 3 weeks post experimental inoculation corresponding to the percentage of leaf area affected by necrotic spots according to Cellini et al [62]. No statistical difference was observed among 'Hort16A', 'Jintao' and 'Hayward'.

eradicate infected tissues; however, it may facilitate the efficacy of spray treatments.

The recirculation of water from infected orchards for rootdrip irrigation also promotes Psa spread [62]. This observation conflicts with the impossibility to experimentally infect plants by root application of Psa suspensions. Thus, infection via roots may be relatively inefficient, but still of some importance in cultural conditions. Alternatively, Psa surviving in the soil or litter may significantly contribute to secondary spread.

Pollination is a key determinant of fruit size and quality. However, Psa may be vectored by pollen granules, and

'Zesy002' showed a significantly lower disease index at 14 and 21 days according to Fisher's LSD test for $\mathrm{P} \leq 0.05$ (values labelled with an asterisk). For the data shown of panel $\mathbf{a}, \mathbf{b}$ and $\mathbf{c}$, eight replicates of three plants per each cultivar were used. $\mathbf{d}$ Disease survey performed in ten commercial orchards located in Emilia Romagna, Italy. The data are the average of 3 years (2013-2015). Data obtained by different A. chinensis var. chinensis male and female varieties were averaged. Concerning A. chinensis var. deliciosa, female vines belonged to the cv. 'Hayward', while for male vines data collected from cv. 'Tomuri' and 'Matua' were averaged. Lower case letters indicate statistical differences inside the same variety, whereas, capital letter indicates statistical differences between plant of the same sex belonging to different varieties according to Marascuilo procedure $\left(\chi^{2}=0.05\right)$

flowers are considered a high-risk point of infection [50]. For this reason, only certified pollen from Psa-free orchards should be used for artificial pollination, which is commonly performed in commercial orchards.

Apart from agricultural practices, which may be optimized to minimize the chance of Psa infection, other uncontrolled factors contribute to bacterial spread. Insects, including pests (Metcalfa pruinosa) and pollinators, may disperse the bacterium within the orchard [69-71]. However, as Psa does not survive long either in M. pruinosa guts or in beehives, longrange or long-term vectoring by insects seems unlikely. 


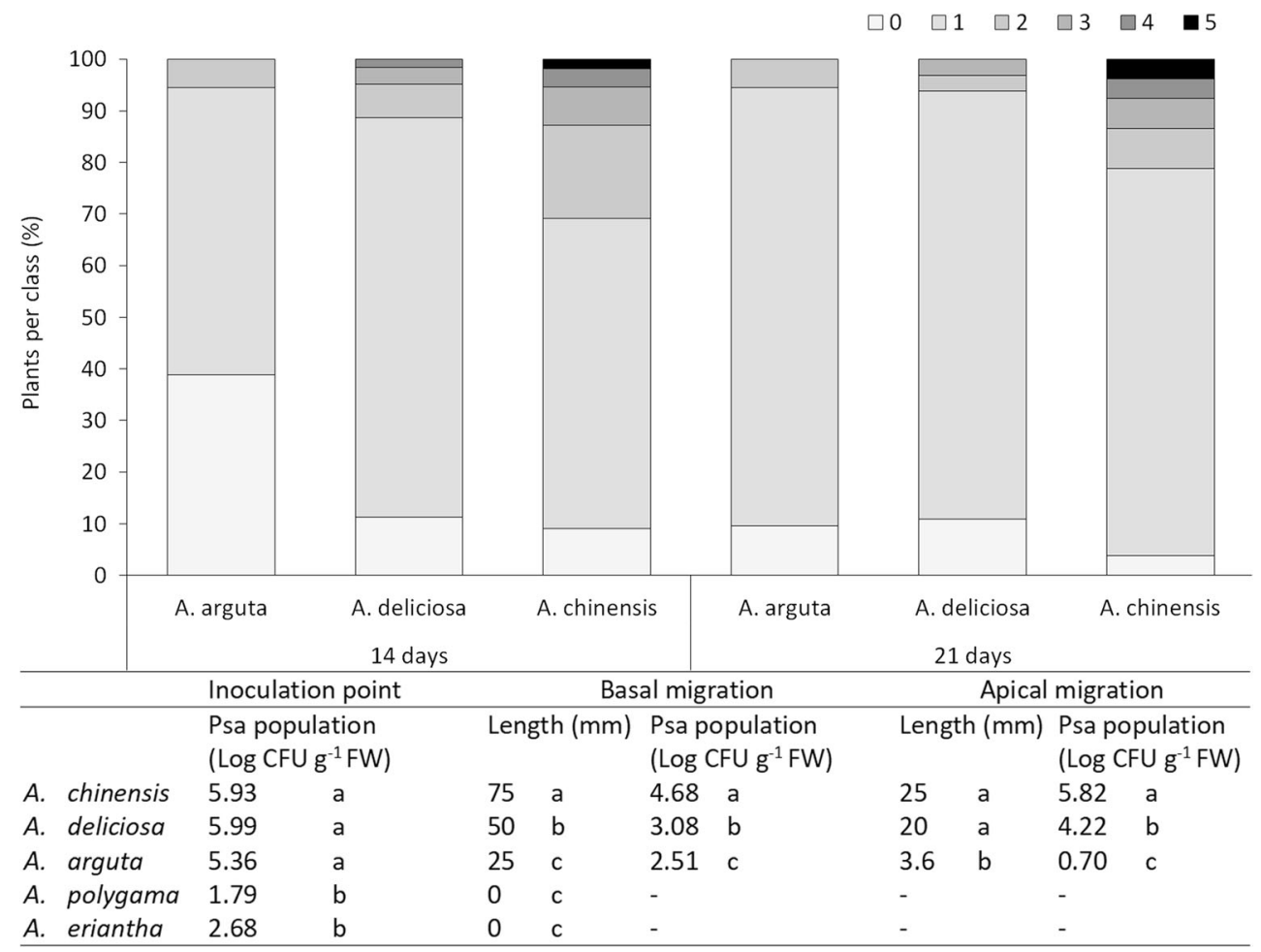

Fig. 7 Distribution of leaves with different disease severity in Actinidia arguta, A. chinensis var. deliciosa and A. chinensis var. chinensis measured at 14 and 21 days after inoculation. For clarity, A. chinensis var. deliciosa and $A$. chinensis var. chinensis are reported in the figure as $A$. deliciosa and $A$. chinensis, respectively. 0 : healthy leaf; $1:<1 \%$ of the leaf area affected; $2: 1-2 \%$ of the leaf area affected, single spots, few coalescent spots; $3: 3-4 \%$ of the leaf area affected, spots start to coalesce; 4: 5-9\% of the leaf area affected, coalescent spots covering veins and

increase in size; $5:>10 \%$ of the leaf area affected. Inoculation was performed by spraying 40 seedling per species with a Pseudomonas syringae pv. actinidiae suspension (CFBP7286 at $10^{7} \mathrm{CFU} \mathrm{mL}^{-1}$ ). The table reports the migration of pathogen inside different Actinidia species. The experiment was performed on 12 potted seedling per species. Values in the same column labelled with different letters are significantly different according to Fisher's LSD test $(P<0.05)$

suggesting that, in nature, they may be active as a pathogenic consortium rather than independent pathogens. spread in the orchard $[15,68]$. The present study also allowed to verify that the pathogen can be intercepted by the Petri dishes mainly during prolonged rain events and especially in spring and autumn. Accordingly, the observation of a reduced disease occurrence under plastic covers [72; Donati et al., unpublished results] was explained with a lower exposure of plants to wind and moisture. Also frost events were associated with Psa outbreaks [66], as freeze-thaw cycles promote bacterial growth and production of exudates, which form the primary inoculum for subsequent spread. Frost events during vegetative activity are particularly risky, for the presence of natural entry points (stomata, wounded tissues) that may enable Psa infection. Metagenomic and classical microbiological approaches showed that Psa is generally associated with P. syringae pv. syringae in A. chinensis var. deliciosa and A. chinensis var. chinensis flowers and leaves [73]. Pseudomonas syringae pv. syringae is known to promote ice nucleation [74] and to infect the host through the resulting frost injuries. Therefore, Psa, although not expressing ice nucleation activity, may take advantage from the association with $P$. syringae pv. syringae. The synergistic copresence of two pathovars has been previously observed [73],

\section{Survival in the Environment and Overwinter Strategy}

Psa could not be detected in free soil samples collected from infected orchards, nor in proximity of roots over $1 \mathrm{~cm}$ in diameter. In contrast, a detectable Psa population (approx. $10^{3} \mathrm{CFU} \mathrm{g}^{-1}$ of soil) was found in $40 \%$ of soil samples associate to fine radicles. In autoclaved soil samples, inoculated with a Psa suspension and kept in controlled conditions, Psa survived $\left(6 \times 10^{2} \mathrm{CFU} \mathrm{g}^{-1}\right)$ for up to 15 days. In soil samples containing fine root particles, Psa maintained a higher population $\left(4 \times 10^{3} \mathrm{CFU} \mathrm{g}^{-1}\right)$ for up to 45 days.

In New Zealand, we found that autoclaved soils inoculated with Psa the pathogen population decreased from $1 \times$ $10^{8} \mathrm{CFU} \mathrm{g}^{-1}$ of soil to $2 \times 10^{4} \mathrm{CFU} \mathrm{g}^{-1}$ over a 3 -month period [61]. A similar result was obtained when using sterilized potting mix. Psa could not be detected in three composts commercially prepared in a region where Psa was present but made from non-kiwifruit green waste. When those commercial composts were inoculated with Psa, Psa population 
Fig. 8 Influence of temperature (a) and relative humidity (b) on Pseudomonas syringae pv. actinidiae growth in planta. The endophytic (blue) or epiphytic (red) growth rate at each temperature or humidity is the average of hourly increase of Psa population at the different time points. Only the points showing an exponential growth phase have been considered. The maximal bacterial population attained in the different conditions is also reported. Regression curves for the influence of temperature and humidity on endophytic and epiphytic pathogen growth were also calculated. For each of the regression curve, $R^{2}$ and $p$ values are reported. Standard errors are shown

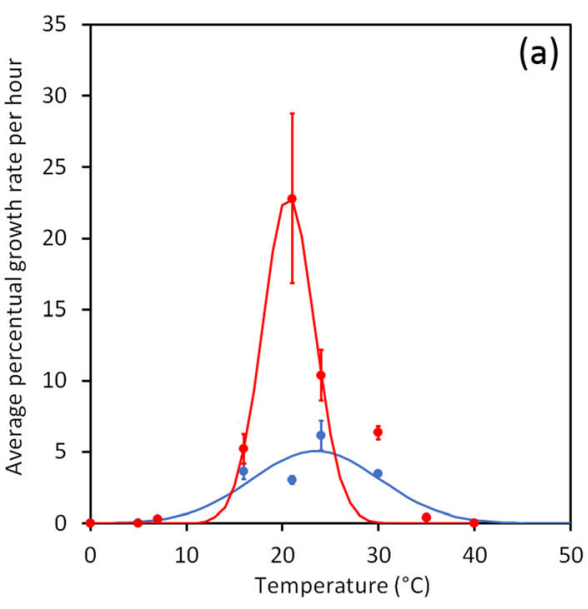

$Y=22.92451 * e^{\frac{-(x-20.62819)^{2}}{2 * 2.7091^{2}}}$
$\mathrm{R}^{2}=0.914 ; \mathrm{P}=0.001347$
$Y=5.062933 * e^{\frac{-(x-23.45998)^{2}}{2 * 6.703795^{2}}}$
$\mathrm{R}^{2}=0.8588 ; \mathrm{P}=0.005817$

Maximal population Temperature $\left.\left({ }^{\circ} \mathrm{C}, \pm 2\right)\right)$ (CFU g $\left.{ }^{-1} \mathrm{FW}\right)$

\begin{tabular}{lcccc} 
& 16 & 21 & 24 & 35 \\
\cline { 2 - 5 } Epiphytic & $1.9 \times 10^{8}$ & $2.3 \times 10^{5}$ & $1.9 \times 10^{6}$ & $6.8 \times 10^{7}$ \\
Endophytic & $1.4 \times 10^{5}$ & $1.1 \times 10^{6}$ & $2.0 \times 10^{8}$ & $7.2 \times 10^{5}$ \\
\hline
\end{tabular}

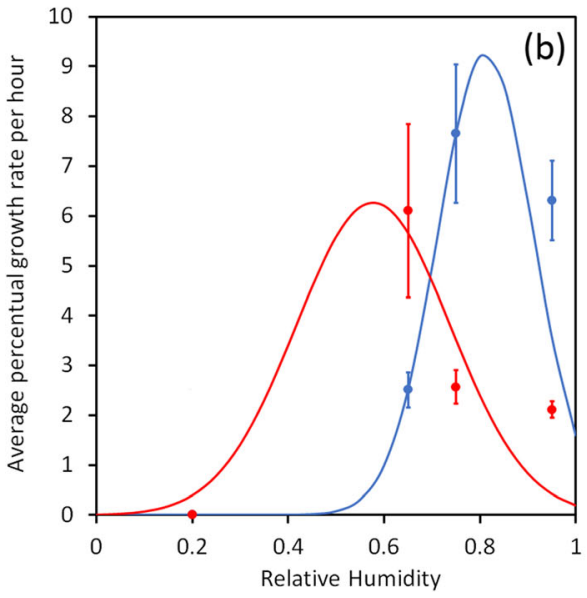

$Y=9.269284 * e^{\frac{-(x-0.8120757)^{2}}{2 * 0.1003127^{2}}}$

$\mathrm{R}^{2}=1.000 ; \mathrm{P}=1.9 * 10^{-8}$

\begin{tabular}{lccc}
\hline $\begin{array}{l}\text { Maximal population } \\
\left.\text { (CFU g } \text { g }^{-1} \mathrm{FW}\right)\end{array}$ & \multicolumn{3}{l}{ Relative Humidity $(\%, \pm 5)$} \\
\hline & 65 & 75 & 90 \\
\cline { 2 - 4 } Epiphytic & $6.6 \times 10^{6}$ & $1.5 \times 10^{6}$ & $5.0 \times 10^{6}$ \\
Endophytic & $2.5 \times 10^{5}$ & $1.5 \times 10^{8}$ & $2.5 \times 10^{5}$ \\
\hline
\end{tabular}

numbers decreased in 7 days or less, from c. $10^{8} \mathrm{CFU} \mathrm{g}^{-1}$ to below the threshold of detection [75].

Psa survived on fallen leaves and pruning wood litter for 6 months (end of the experiment). During the first 2 months, all the samples harboured a viable Psa population, decreasing to 6 and 15\% incidence (in orchard and controlled conditions, respectively) in the last sampling date. In both cases, also Psa population decreased during time. In orchard conditions, during the first 2 months the average Psa population was $3 \times 10^{3} \mathrm{CFU} \mathrm{g}^{-1}$, while in controlled conditions, in litter inoculated with $10^{8} \mathrm{CFU} \mathrm{mL}^{-1}$, it was $9 \times 10^{4} \mathrm{CFU} \mathrm{g}^{-1}$, while, by the end of the experiment the average Psa population was approximately $10^{2} \mathrm{CFU} \mathrm{g}^{-1}$.

The pathogen was not isolated from any of the water sources sampled (i.e. river, stream and pond inside the orchard). However, in controlled conditions, Psa $(2 \times$

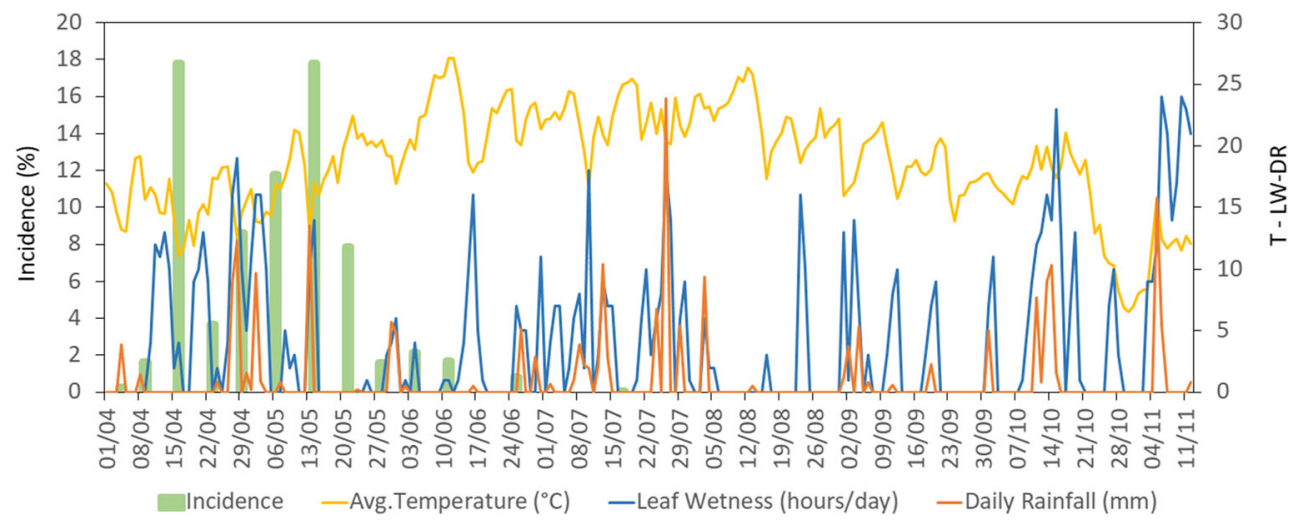

Fig. 9 Incidence of Pseudomonas syringae pv. actinidiae primary symptoms in A. chinensis var. deliciosa (cv 'Hayward') in relation to daily average temperature, leaf wetness and rainfall. Symptom development had a peak from April to May and almost stopped thereafter. The presented data are calculated as the average of three locations during 2014. Bud break occurred at March 26. Experiments performed in 2013 and 2015 provided comparable results 
Fig. 10 Influence of leaf age in susceptibility to Pseudomonas syringae pv. actinidiae infection. a Incidence of symptomatic plants in A. chinensis var. chinensis (cv 'Hort 16A') after inoculation of leaves between 0 and 10 weeks from bud break. b Incidence of $A$. chinensis var. deliciosa (cv. 'Hayward'). Experiments shown in panel (a) and (b) were conducted in controlled conditions. Each hollow point represents the incidence in a single plant. Solid points are the average of at least seven plants. c Progression of Psa incidence on A. chinensis var. deliciosa leaves of different ages. Leaf age is expressed as the day of leaf emergence after the bud break (DABB). Data are the average of 2 years of experiments performed on three geographical locations (Emilia Romagna, Italy)
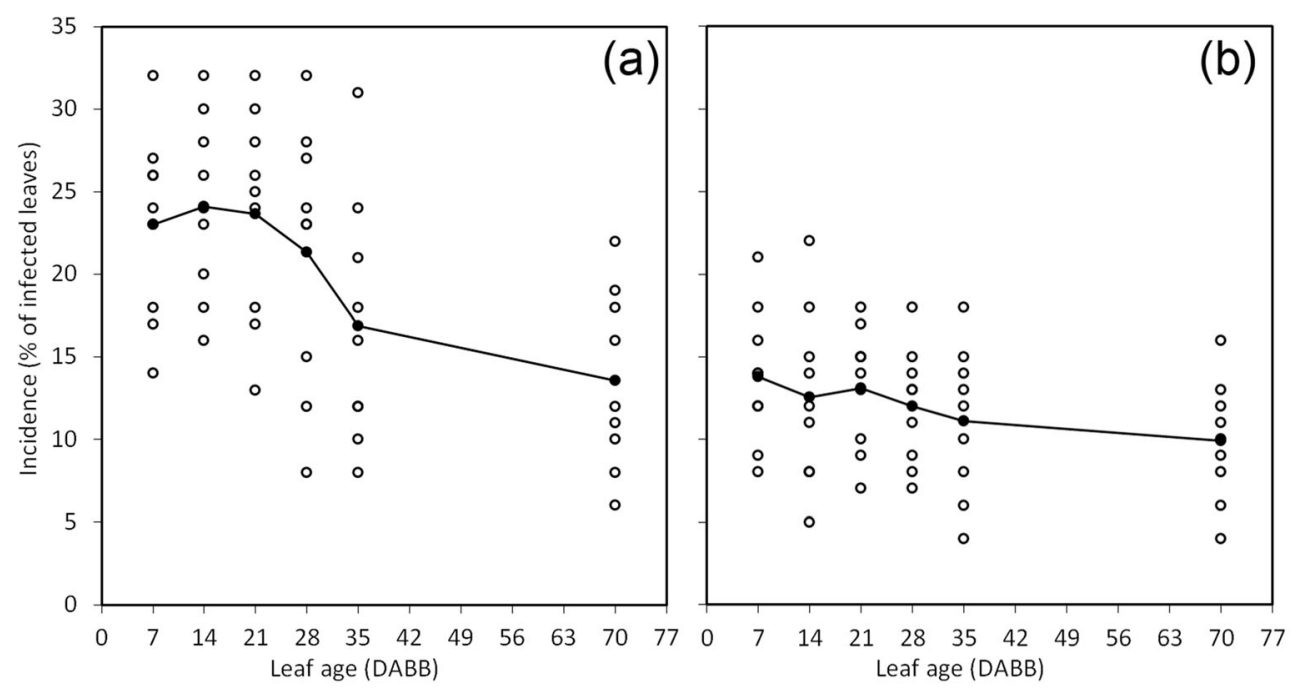

$7 \mathrm{DABB}=14 \mathrm{DABB}=21 \mathrm{DABB}=28 \mathrm{DABB}=35 \mathrm{DABB}=42 \mathrm{DABB}=49 \mathrm{DABB}=56 \mathrm{DABB}=63 \mathrm{DABB} 70 \mathrm{DABB}$

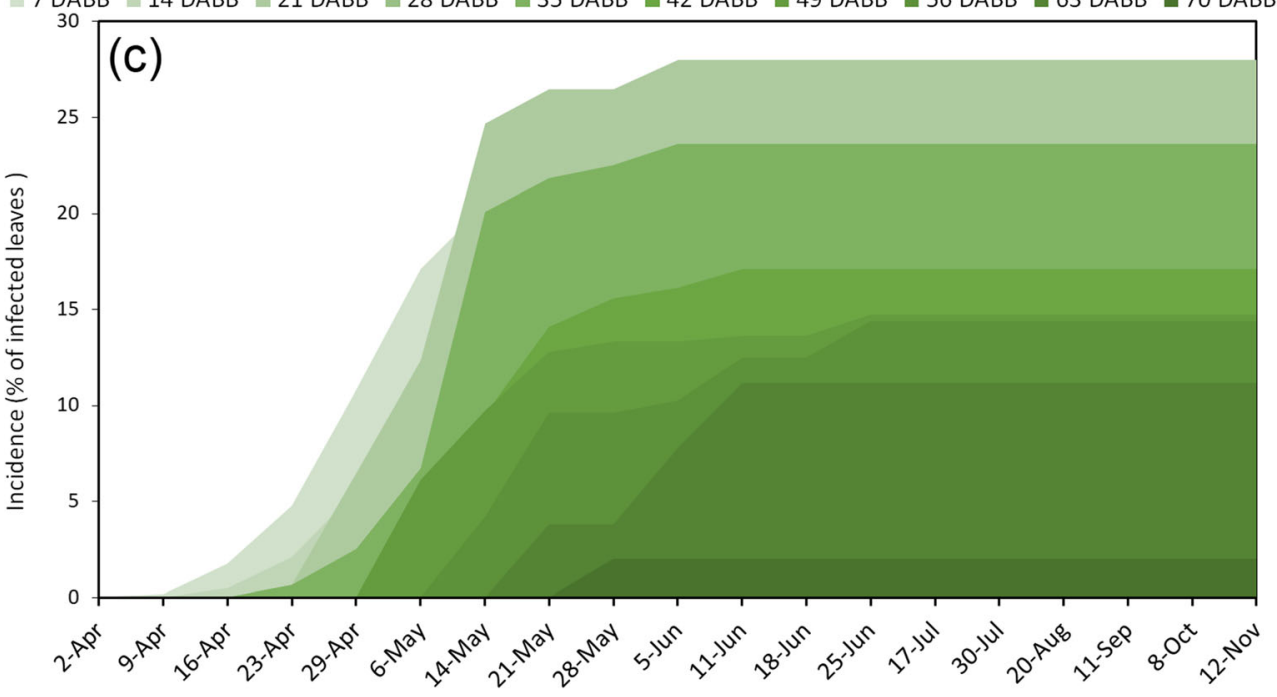

$10^{7} \mathrm{CFU} \mathrm{mL}^{-1}$ ) inoculated in distilled sterile water could survive up to 9 days. In rainwater and superficial water samples, collected in a Psa-free area, viable bacteria were detectable for 4 days. These findings confirm the results obtained by Vanneste et al., [61]. After filter sterilization, the same water samples allowed Psa survival for at least 3 months (end of the experiment) with a population of approx. $3 \times 10^{3} \mathrm{CFU} \mathrm{mL}^{-1}$. Experiments performed in similar conditions resulted in Psa survival up to 30 months [61]. In previous work, a significantly higher disease incidence was observed when irrigation water was taken from local basins with no access to running water [62]. These data, although in partial contrast, suggest that Psa may persist in water sources at concentrations below the detection limit, but still posing an increased risk of contamination.

Psa occurrence on non-host plants commonly found in kiwifruit orchard was sporadic (Table 3). At bud break (BBCH 07 ) and fruit set stages (BBCH 69), but not at harvest (BBCH 81), Psa was commonly isolated from Calystegia sylvatica and Capsella bursa-pastoris with an epiphytic population of $2 \times 10^{5}$ and $1.5 \times 10^{4} \mathrm{CFU} \mathrm{g}^{-1} \mathrm{FW}$, respectively. Psa was also found on Agropyron repens, Bellis perennis, Chenopodium album, Cichorium intybus, Malva spp., Plantago sp., Picris echioides, Taraxacum officinale and Chamaerops humilis. Only plants collected in proximity of infected kiwifruit plants harboured a detectable epiphytic population of Psa. In controlled conditions, Psa was able to survive on non-host plants between 4 and 8 days. Similar results were obtained for Cryptomeria japonica, Pinus radiata and Casuarina cunnighamiana which are commonly used in New Zealand as shelter belts around kiwifruit orchards [61, 76]. Thus, exuding kiwifruit plants or wind-driven cells are likely to be the source of Psa inoculum for the contamination of non-host species [18].

Concerning the overwinter survival, Psa could be isolated from all the plant tissues considered in these experiments (Table 4). Psa population $\left(10^{5} \mathrm{CFU} \mathrm{g}^{-1} \mathrm{FW}\right)$ was found on dormant buds. Up to $40 \%$ and $17 \%$ of dormant buds 
harboured Psa in A. chinensis var. chinensis and A. chinensis var. deliciosa, respectively. In symptomless canes, Psa was isolated only in proximity of buds. Psa was also found in all the trunk samples collected in proximity of visible cankers (up to $15 \mathrm{~cm}$ from the symptoms). Among the plants showing secondary symptoms during the previous season, a considerable fraction (80\% of A. chinensis var. chinensis and $40 \%$ of A. chinensis var. deliciosa samples) harboured a high Psa population $\left(1.2 \times 10^{8} \mathrm{CFU} \mathrm{g}^{-1} \mathrm{FW}\right)$ inside the root system. Psa overwintering population was generally higher in $A$. chinensis var. chinensis than $A$. chinensis var. deliciosa possibly reflecting the higher susceptibility of the first species. In both species, Psa incidence in buds increased with the breaking of dormancy, suggesting a reactivation of the pathogen in concurrence with an increase of the host metabolic activity. The high root pressure occurring at the end of dormancy, by bringing water from the root apparatus to the opening buds, sustains and increases their metabolism [77]. Psa may exploit the xylematic water transport to migrate from the roots and trunk, where there is the highest overwintering incidence, to buds causing the failure of bud break and the wilting of young sprouts that are common symptoms in early spring.

The high root pressure at bud break may also contribute to the reactivation of cankers and to the formation of new ones. The root pressure may provide both water and nutrients for Psa growth and the pressure to facilitate exudation. In these conditions, in xylematic vessels plugged by a rapid Psa

Table 3 Incidence and epiphytic population of Pseudomonas syringae pv. actinidiae in herbaceous plants commonly found in kiwifruit orchards. Three samplings were performed, at bud break (BBCH 07), fruit set (BBCH 69) and harvest (BBCH 81) in an A. chinensis var. chinensis orchard in Faenza, Emilia Romagna-Italy. The data represent the average of the 3 sampling dates. Plants were collected only in proximity of kiwifruit vines presenting exuding cankers

\begin{tabular}{lll}
\hline & Incidence (\%) & Population (CFU g $\left.{ }^{-1} \mathrm{FW}\right)$ \\
\hline Calystegia sylvatica & 44 & $2.0 \times 10^{5}$ \\
Capsella bursa-pastoris & 44 & $1.5 \times 10^{4}$ \\
Taraxacum officinalis & 25 & $1.4 \times 10^{3}$ \\
Agropyron repens & 20 & $2.4 \times 10^{3}$ \\
Bellis perennis & 20 & $<10^{2}$ \\
Chenopodium album & 11 & $9.7 \times 10^{2}$ \\
Cichorium intybus & 11 & $2.4 \times 10^{3}$ \\
Malva spp. & 7 & $8.3 \times 10^{2}$ \\
Plantago spp. & 7 & $2.4 \times 10^{2}$ \\
Picris echioides & 7 & $<10^{2}$ \\
Chamaerops humilis & 7 & $<10^{2}$ \\
Chenopodium rubrum & 0 & 0 \\
Myosotis arvensis & 0 & 0 \\
Urtica dioica & 0 & 0 \\
Glechoma hederacea & 0 & 0 \\
Veronica persica & 0 & 0 \\
\hline
\end{tabular}

growth and the hydration and swelling of the bacterial exopolysaccharides, the water pressure caused by the end of dormancy may lead to cracking and exudation of the trunk, leaders and canes.

\section{Disease Cycle}

The disease cycle of the bacterial canker is shown in Fig. 11. During late winter, in concurrence with the late stage of plant dormancy, xylem functionality reactivates leading to the development of root pressure, defined as positive xylem pressure that arises in the roots. Root pressure rise contributes to the swelling of dormant buds which preludes to bud break. Root pressure also results in copious bleeding (exudation) from the xylem if pruning cuts are made during this time [77]. The high root pressure at bud break may also contribute to the reactivation of cankers and to the formation of new ones. In these conditions, in xylematic vessels plugged by a rapid Psa growth and the hydration and swelling of the bacterial exopolysaccharides, the water pressure caused by the end of dormancy may lead to cracking and exudation of the trunk, leaders and canes. Exuding cankers provide the primary source of inoculum [78]. In late winter or early spring, environmental conditions are very favourable for disease

Table 4 Incidence and endophytic population of Pseudomonas syringae pv. actinidiae in overwintering tissues of $A$. chinensis var. chinensis and A. chinensis var. deliciosa. Experiments were performed in screenhouse without controlled environmental conditions. During the first season, inoculation of the plant was performed by contaminating a single flower cluster with a pathogen suspension $\left(1.5 \times 10^{8} \mathrm{CFU} \mathrm{mL}^{-1}\right)$. All the plant developed primary symptoms (including failure of bud break, leaf spots, twig dieback and flower necrosis) during spring, while only $24 \%$ of them developed secondary symptoms (i.e. cankers) before leaf fall. During the second season, 1 month before bud break, all plants were removed and analysed. For each variety, eight replicates of three plants each were inoculated

\begin{tabular}{|c|c|c|c|c|}
\hline \multirow[t]{2}{*}{ Tissue } & \multicolumn{2}{|c|}{ A. chinensis var. chinensis } & \multicolumn{2}{|c|}{ A. chinensis var. deliciosa } \\
\hline & $\begin{array}{l}\text { Incidence } \\
(\%)\end{array}$ & $\begin{array}{l}\text { Population } \\
\left(\text { CFU g }^{-1}\right)\end{array}$ & $\begin{array}{l}\text { Incidence } \\
(\%)\end{array}$ & $\begin{array}{l}\text { Population } \\
(\text { CFU g g }\end{array}$ \\
\hline \multicolumn{5}{|l|}{ Trunk } \\
\hline Asymptomatic & 80 & $2.8 \times 10^{8}$ & 65 & $3.9 \times 10^{7}$ \\
\hline Near cankers & 100 & & 100 & \\
\hline \multicolumn{5}{|l|}{ Roots: } \\
\hline Rootstock & 80 & $2.2 \times 10^{8}$ & 60 & $5.3 \times 10^{7}$ \\
\hline$>1 \mathrm{~cm}$ & 80 & $1.2 \times 10^{8}$ & 40 & $3.2 \times 10^{6}$ \\
\hline$<1 \mathrm{~cm}$ & 50 & $4.5 \times 10^{8}$ & 40 & $5.4 \times 10^{6}$ \\
\hline \multicolumn{5}{|l|}{ Buds: } \\
\hline Dormant & 40 & $1.1 \times 10^{5}$ & 17 & $6.7 \times 10^{1}$ \\
\hline Swelling & 60 & $9.0 \times 10^{4}$ & 58 & $5.3 \times 10^{1}$ \\
\hline Opening & 67 & $3.0 \times 10^{4}$ & 70 & $1.8 \times 10^{3}$ \\
\hline
\end{tabular}




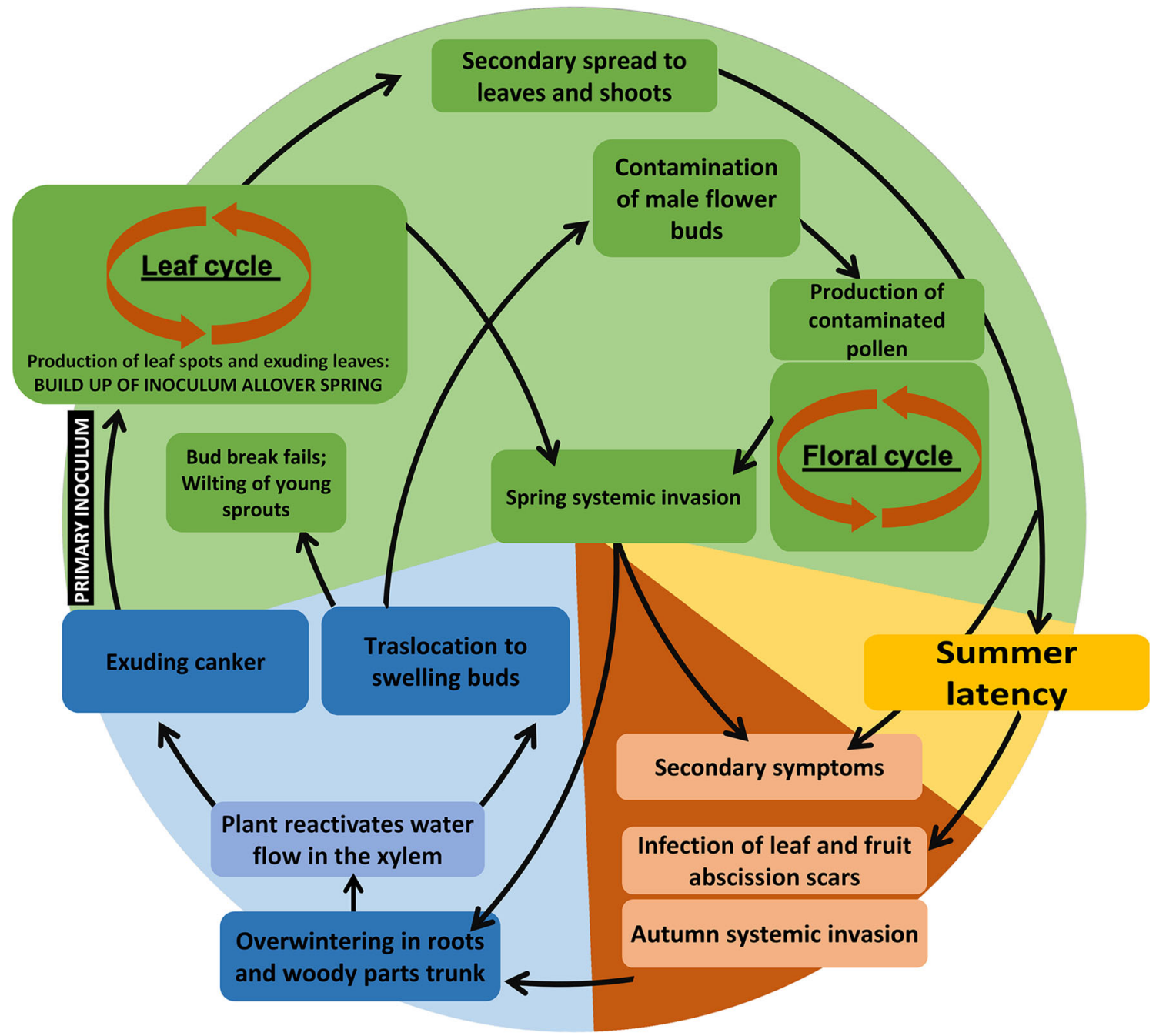

Fig. 11 Disease cycle of the bacterial canker of Actinidia. Colors refer to winter (blue), spring (green), summer (yellow) and autumn (brown)

development and primary infection can be facilitated by physical damage caused by frost, high winds and rain $[49,79]$.

In spring, Psa cells spread from the exuding cankers to leaves and young shoots. On leaves, under favourable conditions, the pathogen multiplies epiphytically, rapidly reaching the infection threshold. Infection occurs primarily via stomata (Fig. 3) $[10,48,80]$. For the onset of the infection, leaf wetness is necessary. Indeed, the water film connecting the plant surface with the stomatic chamber and spongy mesophyll is necessary both for bacterial multiplication and for the migration inside the host tissues $[45,81]$. Psa strains belonging to biovar 2 produce coronatine [47], which, among other effects, contrasts stomata closure [82]. However, coronatine does not appear to be strictly required for virulence, since the genes for its biosynthesis are not present in any strain of the biovar 3, even though they are highly virulent [33]. Such strains, in turn, may produce ethylene [5] that can also suppress ABAmediated stomata closure [83, 84]. In addition, ethylene may support pathogen growth and colonization within the plant tissues, due to its antagonistic role against SA-mediated defences [65]. In favourable, high humidity conditions, leaf spots can also produce bacterial exudates (Fig. 3a), starting a spring leaf cycle by providing the inoculum for a secondary spread of the disease to healthy shoot and leaves throughout spring.

At the end of winter, the increasing root pressure also facilitates the migration of Psa from overwintering organs, such as the roots, to buds, where the pathogen multiplies (Fig. 4a) and can cause the failure of bud break or the shoot dieback, which are common symptoms in early spring. In infected flower buds, Psa can internally colonize the anthers, leading to the production of infected pollen [50]. Pollen-mediated dispersal contributes to a rapid spread inside the orchard. The flower cycle provides the main source of inoculum during spring, when the environmental conditions are highly favourable for the pathogen growth in plant (Fig. 11). During the flower cycle, the spread from plant to plant is facilitated by pollinators [50]. Both leaf and flower infection 
lead to systemic infection in spring, that may result in secondary symptoms (i.e. cane dieback and canker on leaders) during the following autumn.

With the rise of temperature and the decrease of leaf wetness, the formation and development of symptoms is arrested. When average daily temperature exceeds $22^{\circ} \mathrm{C}$ and leaf wetness is for more than 3 days below $4 \mathrm{~h}$ per days, the disease undergoes a latency period that, in Italian conditions, overlaps with the summer period.

At the beginning of autumn, as soon as the environmental conditions become more favourable for the disease, secondary symptoms appear, such as cane withering and trunk cankers. These symptoms provide the source of inoculum for a secondary spread of the disease which may lead to systemic invasion. In this phase, leaf and fruit abscission scars represent the main entry points for the pathogens.

\section{Conclusions}

This work provides an in-depth assessment of Psa dependence on environmental parameters, and host-pathogen relations that are crucial for the epidemiology of the bacterial canker of kiwifruit. While, in the past, the research has been mostly focused on methods for the control of pathogen population or for the stimulation of plant defences [85], it has become evident more recently that agricultural practices and the control of environmental orchard conditions may also contribute significantly to control of Psa [62].

The microscopic observations allowed to elucidate the infection process and to show how the bacterium penetrates in the host plant and colonizes the different tissues. Psa was able to infect the plant via stomata, damaged trichomes, flowers, lenticels, buds at different developmental stage (BBCH 0009), leaf abscission scars and pruning cuts, whilst Psa was unable to infect plants via roots. Therefore, all these entry points need to be protected in order to minimize the risk of Psa infection. After invading the host tissues, the pathogen can colonize the periderm, the sclereids, the pith and the xylem. However, the migration inside the host tissue occurs probably mainly through xylem vessels. Migration can be both basipetal and acropetal and Psa can move across branching nodes.

Thus, the information presented here may integrate the current disease control strategies, indicating as possible targets for disease control not only Psa viability, but also its fitness in the epiphytic niche, the penetration into the apoplast (infection), the systemic colonization of the host, and the survival on non-host species.

Funding Information The work was funded by the European Union's Seventh Framework Programme for research, technological development and demonstration under grant agreement no 613678 (DROPSA-
Strategies to develop effective, innovative and practical approaches to protect major European fruit crops from pests and pathogens).

\section{References}

1. Balestra GM, Mazzaglia A, Quattrucci A, Spinelli R, Graziani S, Rossetti A (2008) Cancro batterico su Actinidia chinensis. L'Informatore Agrario 38:75-77

2. Balestra GM, Mazzaglia A, Quattrucci A, Renzi M, Rossetti A (2009) Current status of bacterial canker spread on kiwifruit in Italy. Australas Plant Dis Notes 4:34-36

3. Ferrante P, Scortichini M (2009) Identification of Pseudomonas syringae pv. actinidiae as causal agent of bacterial canker of yellow kiwifruit (Actinidia chinensis Planchon) in Central Italy. J. Phytopathol. 157:768-770

4. Scortichini M, Marcelletti S, Ferrante P, Petriccione M, Firrao G (2012) Pseudomonas syringae pv. actinidiae: a re-emerging, multifaceted, pandemic pathogen. Mol. Plant Pathol. 13:631-640

5. Donati I, Buriani G, Cellini A, Mauri S, Costa G, Spinelli F (2014) New insights on the bacterial canker of kiwifruit (Pseudomonas syringae pv. actinidiae). J Berry Res 4:53-67

6. Vanneste JL (2017) The scientific, economic, and social impacts of the New Zealand outbreak of bacterial canker of kiwifruit (Pseudomonas syringae pv. actinidiae). Annu. Rev. Phytopathol. 55:377-399. https://doi.org/10.1146/annurev-phyto-080516035530

7. Khandan HAN, Worner SP, Jones EE, Villjanen-Rollinson SLH, Gallipoli L, Mazzaglia A, Balestra GM (2013) Predicting the potential global distribution of Pseudomonas syringae pv. actinidiae (Psa). N Z Plant Protect 66:184-193

8. Bartoli C, Lamichane JR, Berge O, Guilbaud C, Varvaro L, Balestra GM, Vinatzer BA, Morris CE (2015) A framework to gauge the epidemic potential of plant pathogens in environmental reservoirs: the example of kiwifruit canker. Mol. Plant Pathol. 16:137-149

9. Cacioppo O (2012) Aggiornamento dell'actinidicoltura mondiale. Kiwi Informa 10(12):5-8

10. Spinelli F, Donati I, Vanneste JL, Costa M, Costa G (2011) Real time monitoring of the interactions between Pseudomonas syringae pv. actinidiae and Actinidia species. Acta Hortic. 913:461-465

11. Vanneste JL, Yu J, Cornish DA, Max S, Clark G (2011) Presence of Pseudomonas syringae pv. actinidiae, the causal agent of bacterial canker of kiwifruit, on symptomatic and asymptomatic tissues of kiwifruit. N Z Plant Protect 64:241-245

12. Ferrante P, Fiorillo E, Marcelletti S, Marocchi F, Mastroleo M, Simeoeoni S, Scortichini M (2012) The importance of the main colonisation site and penetration ites of Pseudomans syringae pv. actinidiae and the prevailing weather conditions in the development of epidemics in yellow kiwifruit, recently observed in Central Italy. J. Plant Pathol. 94:455-461

13. Renzi M, Copini P, Taddei AT, Rosetti A, Gallipoli L, Mazzaglia A, Balestra GM (2012) Bacterial canker on kiwifruit in Italy: anatomical changes in the wood and in the primary infection sites. Bacteriology 102:827-840

14. Gao X, Huang Q, Zhao Z, Han Q, Ke X, Huang L (2016) Studies on the infection, colonization, and movement of Pseudomonas syringae pv. actinidiae in kiwifruit tissues using a GFPuv-labelled strain. PLoS ONE 11:e0151169

15. Serizawa S, Ichikawa T (1993) Epidemiology of bacterial canker fruit of kiwifruit. Infection and bacterial movements in tissue of new canes. Annals of Phytopathological Society of Japan 59:452459

16. Gallipoli L, Butler M, Mazzaglia A, Stockwell P, Lamont I, Zhu L, Liu P, Balestra GM, Poulter RTM (2015) Genomic diversity of 
Pseudomonas syringae pv. actinidiae (PSA) in China. Acta Hortic. 1095:59-64

17. He R, Pu L, Bing J, Xue SZ, Wang XJ, Hu JY, Al Shoffe Y, Balestra GM, Gallipoli L, Mazzaglia A, Li-Wu Z (2018) Genetic diversity of Pseudomonas syringae pv. actinidiae strains from different geographic regions in China. Phytopathology. https://doi.org/10.1094/ PHYTO-06-18-0188-R

18. Liu P, Xue S, Rong H, Hu J, Wang X, Jia B, Gallipoli L, Balestra GM, Liwu Z (2016) Pseudomonas syringae pv. actinidiae isolated from non-kiwifruit plant species in China. Eur. J. Plant Pathol. 145: $743-754$

19. Spinelli F, Ciampolini F, Cresti M, Geider K, Costa G (2005) Influence of stigmatic morphology on flower colonization by Erwinia amylovora and Pantoea agglomerans. Eur. J. Plant Pathol. 113:395-400

20. Chou-Fen L, Ferguson AR (1986) The botanical nomenclature of the kiwifruit and related taxa. New Zeal J Bot 86:183-184

21. Huang H (2016) Kiwifruit: the genus Actinidia. Academic Press, Cambridge, USA

22. Gui YL (1981) A comparative morphological observation of Actinidia chinensis Planch. Var. chinensis and A. chinensis Planch. Var. hispida C. F. Liang. Acta Phytotaxon Sin 19:304-307

23. Zhang ZY (1983) A report on the chromosome numbers of 2 varieties of Actinidia chinensis planch. Acta Phytotaxon Sin 21:161163

24. Zhang J, Beuzenberg EJ (1983) Chromosome numbers in two varieties of Actinidia chinensis planch. New Zeal J Bot 21:353-355

25. Young JM (2012) Pseudomonas syringae pv. actinidae in New Zealand. J. Plant Pathol. 94(S1):5-10

26. Li M, Tan G, Li Y, Xue L (2005) Resistance mechanism of kiwifruit cultivars to Pseudomonas syringae pv. actinidae. Acta Phytophylactica Sinica 32:37-42

27. Balestra GM, Varvaro L (1997) Pseudomonas syringae pv. syringae causal agent of disease on floral buds of Actinidia deliciosa (a. Chev) Liang et Ferguson in Italy. J. Phytopathol. 145:375-378

28. Balestra GM, Varvaro L (1997) Epiphytic survival and control of Pseudomonas viridiflava on Actinidia deliciosa. Acta Hortic. 444: 745-749

29. Mauchline NA, Hill MG (2005) Settlement of armoured scale insects on fruit of commercial Actinidiae spp. N Z Plant Protect 58: 294-298

30. Salinero MC, Vela P, Sainz MJ (2009) Phenological growth stages of kiwifruit (Actinidia deliciosa 'Hayward'). Sci Hortic-Amsterdam 121:27-31

31. Rees-George J, Vanneste JL, Cornish DA, Pushparajah IPS, Yu J, Templeton MD, Everett KR (2010) Detection of Pseudomonas syringae pv. actinidiae using polymerase chain reaction (PCR) primers based on the $16 \mathrm{~S}-23 \mathrm{~S}$ rDNA intertranscribed spacer region and comparison with PCR primers based on other gene regions. Plant Pathol. 59:453-464

32. Petriccione M, Zampella L, Mastrobuoni F, Scortichini M (2017) Occurrence of copper-resistant Pseudomonas syringae pv. syringae strains isolated from rain and kiwifruit orchards also infected by P. s. pv. actinidiae. Eur. J. Plant Pathol. 149:953-968

33. Ferrante P, Scortichini M (2010) Molecular and phenotypic features of Pseudomonas syringae pv. actinidae isolated during epidemics of bacterial canker of yellow kiwifruit (Actinidia chinensis) in Central Italy. Plant Pathol. 59:954-962

34. Lindow SE, Brandl MT (2003) Microbiology of the phyllosphere. Appl. Environ. Microbiol. 69:1875-1883

35. Jacobs JL, Carroll TL, Sundin GW (2005) The role of pigmentation, ultraviolet radiation tolerance, and leaf colonization strategies in epiphytic survival phyllosphere bacteria. Microb. Ecol. 49:104 113
36. Danhor T, Fuqua C (2007) Biofilm formation by plant associated bacteria. Annu. Rev. Microbiol. 61:401-422

37. He Z, Zhang X, Zhong Y, Ye L (2000) Phylogenetic relationships of Actinidia and related genera based on micromorphological characters of foliar trichomes. Genet Resour Crop Ev 47:627-639

38. Monier JM, Lindow SE (2004) Frequency, size, and localization of bacterial aggregates on bean leaf surfaces. Appl. Environ. Microbiol. 70:346-355

39. Melotto M, Underwood W, He SY (2008) Role of stomata in plant innate immunity and foliar bacterial diseases. Annu. Rev. Phytopathol. 46:101-122

40. Brewer CA, Smith WK, Volgemann TC (1991) Functional interaction between leaf trichomes, leaf wettability, and the optical properties of water droplets. Plant Cell Environ. 14:955-962

41. Ascensao L, Pais MS (1998) The leaf capitate trichomes of Leunotis leonurus: histochemistry, ultrastructure and secretion. Ann. Bot. 81: 648-656

42. Olsen DL, Nechols JR (1995) Effects of squash leaf trichomes exudates and honey on adult feeding, survival, and fecundity of the squash bug (heteroptera: Coreidar) egg parasitoid Gyron pennsylvanicum (hymenoptera:Scelionidae). Environ. Entomol. 24:454-458

43. Kim KW (2019) Plant trichomes as microbial habitats and infection sites. Eur J Plant Pathol. https://doi.org/10.1007/s10658-01801656-0

44. Getz S, Fulbright DW, Stephens CT (1983) Scanning electron microscopy of infection sites and lesion development on tomato fruit infected with Pseudomonas syringae pv. tomato. Phytopathology 73:39-43

45. Haefele DM, Lindow SE (1987) Flagellar motility confers epiphytic fitness advantages to Pseudomonas syringae. Appl. Environ. Microbiol. 53:2528-2533

46. Melotto M, Zhang L, Oblessuc PR, He SY (2017) Stomatal defense a decade later. Plant Physiol. 174:561-571

47. Han HS, Koh YJ, Hur JS, Jung JS (2003) Identification and characterization of coronatine-producing Pseudomonas syringae pv. actinidiae. J. Microbiol. Biotechnol. 13:110-118

48. Vanneste JL, Oldham JM, Clark G, Felman CM (2013) Survival of Pseudomonas syringae pv. actinidiae in non-kiwifruit green compost. N Z Plant Protect 66:178-183

49. Serizawa S, Ichikawa T, Takikawa Y, Tsuyumu S, Goto M (1989) Occurrence of bacterial canker of kiwifruit in Japan: description of symptoms, isolation of the pathogen and screening of bactericides. Ann. Phytopathol. Soc. Jpn. 55:427-436

50. Donati I, Cellini A, Buriani G, Mauri S, Kay C, Tacconi G, Spinelli F (2018) Pathways of flower infection and pollen-mediated dispersion of Pseudomonas syringae pv. actinidiae, the causal agent of kiwifruit bacterial canker. Hortic Res 5:56. https://doi.org/10.1038/ s41438-018-0058-6

51. Vanneste JL, Giovanardi D, Yu J, Cornish DA, Kay C, Spinelli F, Stefani E (2011) Detection of Pseudomonas syringae pv. actinidiae in kiwifruit pollen samples. N Z Plant Protect 64:246-251

52. Stefani E, Giovanardi D (2011) Dissemination of Pseudomonas syringae $p v$. actinidiae through pollen and its epiphytic life on leaves and fruits. PhytopatholMediterr 50:489-496

53. Gallelli A, Talocci S, L'Aurora A, Loreti S (2011) Detection of Pseudomonas syringae pv. actinidiae, causal agent of bacterial canker of kiwifruit, from symptomless fruits and twigs, and from pollen. Phytopathol. Mediterr. 50:462-472

54. Biondi E, Galeone A, Kuzmanović N, Ardizzi S, Lucchese C, Bertaccini A (2013) Pseudomonas syringae pv. actinidiae detection in kiwifruit plant tissue and bleeding sap. Ann Appl Biol 162:60-70

55. Balestra GM, Buriani G, Cellini C, Donati I, Mazzaglia A, Spinelli F (2018) First report of Pseudomonas syringae pv. actinidiae on kiwifruit pollen from Argentina. Plant Dis. 102:237. https://doi.org/ 10.1094/PDIS-04-17-0510-PDN 
56. Nardozza S, Martinez-Sanchez M, Curtis C, Datson PM, Montefiori M (2014) Screening the Actinidia germoplasm for different degrees of tolerance, or resistance, to Psa (Pseudomonas syringae pv. actinidiae). Acta Hortic. 1096:351-355

57. Coplin DL, Majerczak DR (1990) Extracellular polysaccharide genes in Erwinia stewartii: directed mutagenesis and complementation analysis. Mol Plant Microbe In 3:286-292

58. Von Bodman SB, Bauer WD, Coplin DL (2003) Quorum sensing in plant-pathogenic bacteria. Annu. Rev. Phytopathol. 41:455-482

59. Mansfield J, Genin S, Magori S, Citovsky V, Sriariyanum M, Ronald P, Dow M, Verdier V, Beer SV, Machado MA, Toth I, Salmond G, Foster GD (2012) Top 10 plant pathogenic bacteria in molecular plant pathology. Mol. Plant Pathol. 6:614-629

60. Ichinose Y, Taguchi F, Mukaihara T (2013) Pathogenicity and virulence factors of Pseudomonas syringae. J. Gen. Plant Pathol. 79: 285-296

61. Vanneste JL, Yu J, Cornish DA, Oldham JM, Spinelli F, Pattemore DE, Moffat B, d'Accolti A (2015) Survival of Pseudomonas syringae pv. actinidiae in the environment. Acta Hortic. 109:105110

62. Mauri S, Cellini A, Buriani G, Donati I, Costa G, Spinelli F (2016) Optimization of cultural practices to reduce the development of Pseudomonas syringae pv. actinidiae, causal agent of the bacterial canker of kiwifruit. J Berry Res 6:355-371

63. Cotrut R, Renzi M, Taratufolo MC, Mazzaglia A, Balestra GM, Stanica F (2013) Actinidia arguta ploidy level variation in relation to Pseudomonas syringae pv. actinidiae susceptibility. Lucrări Științifice 56:29-38

64. Vanneste JL, Cornish DA, Yu J, Stokes CA (2014) First report of Pseudomonas syringae pv. actinidiae the causal agent of bacterial canker of kiwifruit on Actinidia arguta vines in New Zealand. Plant Dis. 98:418. https://doi.org/10.1094/PDIS-06-13-0667-PDN

65. Cellini A, Fiorentini L, Buriani G, Yu J, Donati I, Cornish DA, Novak B, Costa G, Vanneste JL, Spinelli F (2014) Elicitors of the salicylic acid pathway reduce incidence of bacterial canker of kiwifruit caused by Pseudomonas syringae pv. actinidae. Ann Appl Biol 165:441-453

66. Ferrante P, Scortichini M (2014) Frost promotes the pathogenicity of Pseudomonas syringae pv. actinidiae in Actinidia chinensis and A. deliciosa plants. Plant Pathol. 63:12-19

67. Everett KR, Pushparajah IPS, Vergara MJ (2012) Pseudomonas syringae pv. actinidiae on surfaces in the orchard. N Z Plant Protect 65:19-24

68. Froud KJ, Everett KR, Tyson JL, Beresford RM, Cogger N (2015) Review of the risk factors associated with kiwifruit bacterial canker caused by Pseudomonas syringae pv. actinidiae. N Z Plant Protect 68:313-327

69. Pattemore DE, Goodwin RM, McBrydie HM, Hoyte SM, Vanneste JL (2014) Evidence of the role of honey bees (Apis mellifera) as vectors of the bacterial plant pathogen Pseudomonas syringae. Australas. Plant Pathol. 43:571-575

70. Donati I, Mauri S, Buriani G, Cellini A, Spinelli F (2017) Role of Metcalfa pruinosa as a vector for Pseudomonas syringae pv. actinidiae. Plant Pathology J 33:554-560
71. Cellini A, Giacomuzzi V, Donati I, Farneti B, Rodriguez-Estrada MT, Savioli S, Angeli S, Spinelli F (2018) Pathogen-induced changes in floral scent may increase honeybee mediated dispersal of Erwinia amylovora. ISME J. 13:847-859. https://doi.org/10. 1038/s41396-018-0319-2

72. Black MZ, Casonato S, Bent S (2014) Opportunities for environmental modification to control Pseudomonas syringae pv. actinidiae in kiwifruit. Acta Hortic. 1105:353-360

73. Purahong W, Orrù L, Donati I, Perpetuini G, Cellini A, Lamontanara A, Michelotti V, Tacconi G, Spinelli F (2018) Plant microbiome and its link to plant health: host species, organs and Pseudomonas syringae pv. actinidiae infection shaping bacterial phyllosphere communities of kiwifruit plants. Front Plant Sci. 9: 1563. https://doi.org/10.3389/fpls.2018.01563

74. Lindow SE, Arny DC, Upper CD (1978) Distribution of ice nucleation-active bacteria on plants in nature. Appl. Environ. Microbiol. 36:831-838

75. Vanneste JL, Yu J, Cornish DA, Tanner DJ, Windner R, Chapman JR, Taylor RK, Mackay J, Dowlut S (2013) Identification, virulence and distribution of two biovars of Pseudomonas syringae pv. actinidiae in New Zealand. Plant Dis 97:708-719

76. Vanneste JL, Moffat BJ, Oldham JM (2012) Survival of Pseudomonas syringae pv. actinidiae on Cryptomeria japonica, a non-host plant used as shelter belts in kiwifruit orchards. N Z Plant Protect 65:1-7

77. Clearwater MJ, Blattmann P, Luo Z, Lowe RG (2007) Control of scion vigour by kiwifruit rootstocks is correlated with spring root pressure phenology. J. Exp. Bot. 58:1741-1751

78. Kim GH, Kim KH, Son KI, Choi ED, Lee YS, Jung JS, Koh YJ (2016) Outbreak and spread of bacterial canker of kiwifruit caused by Pseudomonas syringae pv. actinidiae biovar 3 in Korea. Plant Pathology J 32:545-551

79. Balestra GM (2004) Use of copper formulations to limit bacterial diseases in kiwifruit. (Speciale Actinidia). Rivista di Frutticoltura e di Ortofloricoltura 66:35-41

80. Michelotti V, Lamontanara A, Buriani G, Orrù L, Cellini A, Donati I, Vanneste JL, Cattivelli L, Tacconi G, Spinelli F (2018) Comparative transcriptome analysis of the interaction between Actinidia chinensis var. chinensis and Pseudomonas syringae pv. actinidiae in absence and presence of acibenzolar-S-methyl. BMC Genomics 19:585. https://doi.org/10.1186/s12864-018-4967-4

81. Xin XF, Kvitko B, Yang He SY (2018) Pseudomonas syringae: what it takes to be a pathogen. Nat Rev Microbiol 16:316-328

82. Melotto M, Underwood W, Koczan J, Nomura K, He SY (2006) Plant stomata function in innate immunity against bacterial invasion. Cell 126:969-980

83. Tanaka Y, Sano T, Tamaoki M, Nakajima N, Kondo N, Hasezawa S (2005) Ethylene inhibits abscisic acid-induced stomatal closure in Arabidopsis. Plant Physiol. 138:2337-2343

84. Wilkinson S, Davies WJ (2009) Ozone suppresses soil drying-and abscisic acid (ABA)-induced stomatal closure via an ethylenedependent mechanism. Plant Cell Environ. 32:949-959

85. Cameron A, Sarojini V (2014) Pseudomonas syringae pv. actinidiae: chemical control, resistance mechanisms and possible alternatives. Plant Pathol. 63:1-11 